\title{
Laju Pertumbuhan Dan Kelangsungan Hidup Ikan Baronang Siganus canalicalatus Yang DiberiJenis Pakan dan Frekuensi Yang Berbeda di Keramba Jaring Apung
}

\author{
*Naiboki Salampessy dan Irawati \\ Politeknik Kelautan dan Perikanan Maluku, \\ Jl. Laksdya Leo Wattimena No.KM, RW.16, Waiheru, Baguala, Kota Ambon, Maluku \\ *e-mail korespondensi : okisalampessy27@gmail.com
}

\begin{abstract}
Absract. This research is about "Growth Rate and Survival Rate of Baronang Siganus canaliculatus Fish Given Different Types of Feed and Frequency in the Floating Net Cages. The research lasted as long as for 6 (six) months from May to October 2018.The design of this study used a factorial Completely Randomized Design (CRD) using 2 factors as treatment, namely: (1) $50 \%$ of the trash fish, 50\% papaya leaves, and 25\% trash fish \& $75 \%$ papaya leaves. (2) the frequency of feeding once, the frequency of feeding 2 times and the frequency of feeding 3 times. This treatment is to see whether there is a significant difference between the treatment of growth rate and survival rate of baronang fish (Siganus canaliculatus) as the research sample. From the research data analyzed using ANOVA, it was found that the type of feed and the frequency of distribution had a significant effect on the growth rate. Based on statistics, the results of this study showed no significant effect between treatments on growth, survival and FCR. Feeding with a composition of 50\% trash fish and 50\% papaya leaves with a frequency of 3 times gave the highest growth rate, survival and FCR values for rabbit fish (Siganus canaliculatus) rearing for 120 days in Floating Net Cages
\end{abstract}

Keywords : Feed, Frequency, Rate of growth, Survival rate, Siganus canaliculatus

\begin{abstract}
Abstrak. Penelitian ini tentang "Laju Pertumbuhan dan Kelangsungan Hidup Ikan Baronang Siganus canaliculatus Yang Diberi Jenis Pakan dan Frekuensi Yang Berbeda di Keramba Jaring Apung. Pelaksanaan penelitian berlangsung selama 6 (enam) bulan mulai bulan Mei sampai dengan Oktober 2018. Desain penelitian ini menggunakan Rancangan Acak Lengkap (RAL) faktorial dengan menggunakan 2 faktor sebagai perlakuan yaitu : (1) jenis pakan 50\% ikan rucah \& 50\% daun pepaya, dan 25\% Ikan rucah \& 75\% daun pepaya (2) frekuensi pemberian pakan 1 kali, frekuensi pemberian pakan 2 kali dan frekuensi pemberian pakan 3 kali. Perlakuan ini untuk melihat apakah terdapat perbedaan yang signifikan antara perlakuan terhadap laju pertumbuhan dan kelangsungan hidup ikan baronang (Siganus canaliculatus) sebagai sampel penelitian. Dari data penelitian yang dianalisis dengan menggunakan ANOVA (sidik ragam) diperoleh bahwa jenis pakan dan frekuensi pemberian memberikan pengaruh yang nyata terhadap laju pertumbuhan. Berdasarkan statistic, hasil dari penelitian ini menunjukkan tidak adanya pengaruh nyata antar perlakuan terhadap pertumbuhan, kelangungan hidup dan FCR. Pemberian pakan dengan komposisi 50\% ikan rucah dan 50\% daun papaya dengan frekuensi pemberian sebanyak 3 kali memberikan nilai laju pertumbuhan, kelangsungan hidup dan FCR tertinggi pada pemeliharaan ikan baronang selama 120 hari di KJA.
\end{abstract}

Kata Kunci : Pakan, Frekuensi, Laju Pertumbuhan, Kelangsungan Hidup, Siganus canaliculatus

\section{PENDAHULUAN}

Keberhasilan dari suatu usaha pemeliharaan ikan Beronang di Keramba Jaring Apung (KJA) dihadapkan pada permasalahan tingginya harga pakan komersil (pellet), padahal dalam kegiatan budidaya, pakan merupakan faktor yang sangat penting dalam menentukan tingkat keberhasilan karena sekitar $60-70 \%$ biaya operasional merupakan komponen biaya pakan, oleh karena itu manajemen produksi yang tepat perlu dilakukan untuk menangani permasalahan ini.

Salah satu alternative yang dapat dilakukan untuk menekan biaya produksi tersebut adalah dengan membuat pakan buatan sendiri. Pembuatan pakan buatan dapat menggunakan teknik yang sederhana dengan memanfaatkan sumber bahan baku local, karena harga yang relative murah dan mudah di dapat. Menurut Britner et al. (1989), banyak bahan yang dapat digunakan untuk pakan buatan, tetapi harus memperhatikan 3 hal yakni jenis ikan dan ketersediaan bahan serta kandungan nutrisi. Upaya mengoptimalkan penggunaan pakan yang akan diberikan pada ikan beronang merupakan suatu tindakan yang dapat menekan biaya dan meningkatkan efisiensi produksi.

Selain pakan buatan berupa pellet yang sudah umum digunakan, ikan rucah, dan daun pepaya dapat menjadi alternative pakan untuk ikan beronang karena sesuai dengan kebiasaan makan ikan yang herbivor, menurut Ismail dalam waspada (1984) menjelaskan bahwa ikan beronang bersifat herbivor tetapi mudah untuk menerima makanan lainnya. Hal tersebut diperkuat oleh Basyari (1988) dengan pengamatannya terhadap isi lambung ikan beronang terdapat rumput laut, selanjutnya dijelaskan bahwa ikan beronang yang hidup di perairan bebas, kemudian dibudidayakan mampu mengkonsumsi pakan baik berupa tumbuhan, maupun pakan buatan seperti pellet.

Di Indonesia usaha pembesaran ikan beronang baru dilakukan dibeberapa tempat, misalnya di kepulauan Seribu Teluk Banten dan Kepulauan Riau. Penelitian pembesaran ikan Beronang telah dilakukan di perairan pulau Pari (kepulauan Seribu) yang meliputi jenis Siganus guttatus, S. Virgatus dan S. Canaliculatus (Romimohtarto,k dan Juwana,S. 2007), sedangkan di Maluku Penelitian terkait pembesaran ikan beronang di Keramba Jaring Apung 
(KJA), baru dilakukan di Balai Budidaya Laut Ambon (BBL) tetapi penelitian ini menggunakan pakan ikan rucah sebagai pakan utamanya (Umar R, dkk 2014), adapun hasil penelitiannya adalah panjang total ikan Beronang $23 \mathrm{~cm}$ dan diperoleh SR 80,7\%. Hal ini sesuai pendapat Polisoc (1975) dalam Widodo (1986) bahwa ukuran panjang total 15,0 - 16,26 di capai selama 5-6 bulan, dalam satu kilogram terdapat 5-6 ekor (166 - 200 gram). Sementara menurut Gundermann et al (1983) dalam Danakusumah (1985) ukuran maksimun yang dapat dicapai oleh ikan Beronang 40 $\mathrm{cm}(1.800 \mathrm{~g})$.

Selain jenis pakan, frekuensi pemberian pakan yang diberikan harus dilakukan secara cermat dan tepat sehingga ikan tidak mengalami kekurangan pakan (under feeding) atau kelebihan pakan (over feeding). Kekurangan pakan akan mengakibatkan pertumbuhan ikan menjadi lambat, ukuran ikan tidak seragam, tubuh tampak kurus dan menimbulkan kanibalisme. Sebaliknya kelebihan pakan akan mencemari perairan dan mengakibatkan kualitas air di sekitarnya menjadi buruk sehingga ikan mudah stres dan pertumbuhannya terhambat. Selain itu daya tahan ikan terhadap penyakit pun menurun sehingga angka mortalitas nya meningkat.

Pepaya merupakan enzim protease yang terdapat pada getah pepaya. Enzim tersebut digunakan untuk pemecahan atau penguraian yang sempurna ikatan peptide dalam protein, sehingga protein yang terurai menjadi ikatan peptida yang lebih sederhana karena papain mampu mengatalisis reaksi-reaksi hidrolisis suatu substrat (Muchtadi et al, 1992). Hasil dari pemberian pepaya pada pakan mempengaruhi terhadap laju pertumbuhan ikan dan pakan yang telah diberikan enzim pepaya dapat tercerna dengan baik akan menghasilkan pasokan energi. Energi yang berasal dari pakan inilah yang digunakan untuk maintenance dan aktifitas tubuh, sehingga kelebihan energy digunakan untuk pertumbuhan. Selain itu pemanfaatan dengan baik karena didukung oleh protease pepaya dalam pakan sehingga perombakan pakan menjadi unsur-unsur yang lebih sederhana akan lebih banyak. Dengan unsurunsur sederhana inilah maka sintesis asam amino untuk menjadi protein tubuh juga lebih besar sehingga pertambahan bobot akan lebih besar.

Masih kurangnya informasi Penelitian penggunaan pakan rucah dan daun pepaya serta frekuensi pemberian pakan yang tepat untuk pertumbuhan dan kelangsungan hidup ikan beronang di Keramba aring Apung (KJA), sehingga penelitian ini perlu dilakukan.

\section{Lokasi dan Waktu}

\section{METODE PENELITIAN}

Kegiatan penelitian ini dilaksanakan di Keramba Jaring Apung Sekolah Usaha Perikanan Menengah (SUPM) Waiheru Ambon.

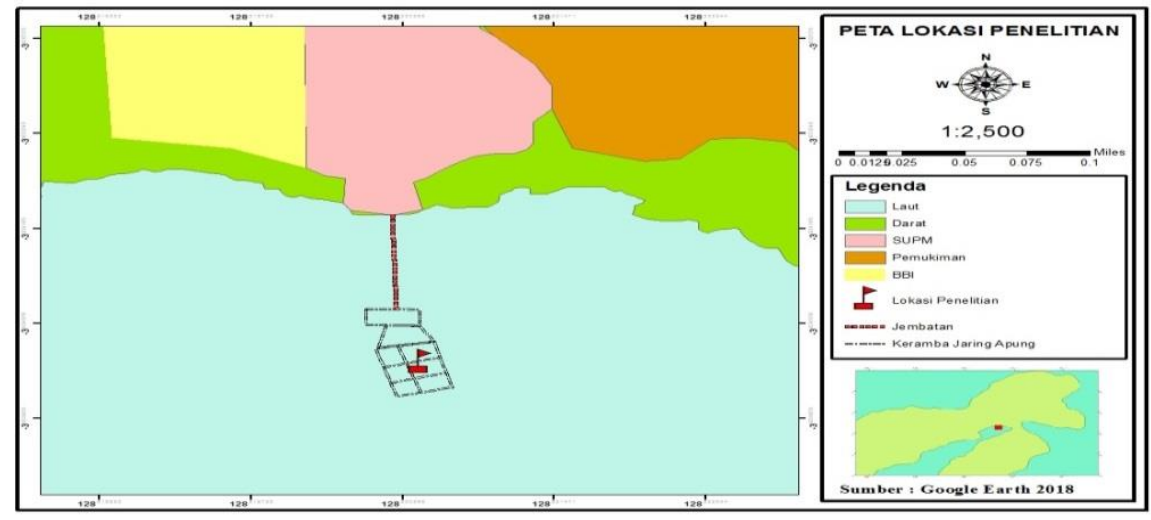

Gambar 1. Peta Lokasi Penelitian

Sedangkan tempat analisis proximate pakan di Laboratorium Balai Riset dan Standarisasi Industri Ambon. Pelaksanaan penelitian ini berlangsung selama 6 (enam) bulan mulai dari bulan Mei sampai dengan Oktober 2018, namun untuk proses pemeliharaan ikan dilakukan selama 4 (empat) bulan mulai dari bulan Juni sampai dengan September 2018.

\section{Metode Penelitian}

Penelitian yang dilakukan bersifat eksperimental. Menurut Nazir (1988), metode penelitian eksperimental adalah observasi di bawah kondisi buatan (artificial condition), dimana kondisi tersebut dibuat dan diatur oleh peneliti. Dengan demikian, penelitian eksperimental ini merupakan penelitian yang dilakukan dengan mengadakan manipulasi terhadap objek penelitian.

Penelitian ini bersifat eksperimen dengan menggunakan rancangan percobaan yaitu dengan Rancangan Acak Lengkap (RAL) faktorial dengan menggunakan 2 faktor sebagai perlakuan yaitu : 
Naiboki Salampessy dan Irawati. Laju Pertumbuhan Dan Kelangsungan Hidup Ikan Baronang Siganus canalicalatus Yang DiberiJenis Pakan dan Frekuensi Yang Berbeda di Keramba Jaring Apung

1. Faktor A adalah perlakuan jenis pakan yaitu, Ikan rucah $50 \%$ \& daun pepaya $50 \%$ dan Ikan rucah $25 \%$ dan daun pepaya $75 \%$

2. Faktor B adalah perlakuan frekuensi pemberian pakan yaitu 1,2\&3 kali dan dilakukan dengan 3 kali ulangan

Sedangkan untuk control digunakan pakan pellet dengan frekuensi pemberian 1, $2 \& 3$ tetapi tidak pakai ulangan. Dari rancangan tersebut diperoleh kombinasi perlakuan seperti yang disajikan pada tabel 1.

Tabel 1. Rancangan kombinasi perlakuan penelitian

\begin{tabular}{lcccc}
\hline \multirow{2}{*}{ Jenis Pakan (p) } & \multirow{2}{*}{ Ulangan } & \multicolumn{3}{c}{ Frekuensi Pemberian (f) } \\
\cline { 3 - 5 } & & 1 kali (f1) & 2 kali (f2) & 3 kali (f3) \\
\hline Pellet (p1) & Kontrol & P1f1 & P1f2 & P1f3 \\
Ikan Rucah 50\% dan Daun Pepaya 50\% (p2) & \multirow{3}{*}{ kali } & P2f1 & P2f2 & P2f3 \\
& & P2f1 & P2f2 & P2f3 \\
Ikan Rucah 25\% dan Daun Pepaya 75\% (p3) & \multirow{2}{*}{ P kali } & P3f1 & P2f2 & P2f3 \\
& & P3f1 & P3f2 & P3f3 \\
& & P3f1 & P3f2 & P3f3 \\
\hline
\end{tabular}

Keterangan :

$\mathrm{P} \quad$ : Jenis pakan

p1 : Pellet

P2 : Kombinasi (50\% rucah $+50 \%$ daun pepaya)

P3 : Kombinasi ( $25 \%$ rucah $+75 \%$ daun pepaya) f : Frekuensi Pemberian

f1 : 1 kali

f2 : 2 kali

f3 : 3 kali

Tabel 2. Kandungan proximate bahan uji

\begin{tabular}{cccc}
\hline Kandungan & Pellet $(\%)$ & Ikan Layang $(\%)$ & Daun Pepaya $(\%)$ \\
\hline Air & 8,13 & 76,63 & 81,09 \\
Abu & 11,66 & 3,19 & 2,07 \\
Lemak & 11,73 & 1,71 & 0,85 \\
Protein & 52,59 & 22,02 & 7,60 \\
Karbohidrat & 18,67 & 0.83 & 2,55 \\
\hline
\end{tabular}

Sebelum pakan diberikan pada ikan dengan langkah-langkah sebagai berikut : (1) Kombinasi ikan rucah dan daun pepaya terlebih dahulu dicacah halus-halus dan sesuai ukuran mulut ikan kemudian dicampur, (2) menimbang pakan uji sesuai dosis pemberian, (3) menempatkan pakan uji pada anco yang telah digantung di dalam warring.

Menurut Rachmansyah (1993), jumlah pakan yang diberikan yakni 4\% dari total berat ikan/hari, ikan Beronang ditimbang bobotnya untuk menentukan jumlah pakan yang akan diberikan setiap hari (4\% dari bobot biomass), kegiatan ini dilakukan selama 30 hari sekali. Menurut Rachmansyah (1993), bahwa pemberian pakan yang sembrono dan tergesa-gesa akan menyebabkan 5-10 \% pakan yang diberikan akan terbuang keluar. Selain jenis pakan, dalam penelitian ini juga aplikasikan 3 frekuensi pemberian pakan, yakni 1 kali pemberian, 2 kali pemberian dan 3 kali pemberian. Untuk 1 kali pemberian pakan diberikan pada pukul 08.00 WIT, 2 kali pemberian diberikan pada : pukul 08.00 WIT dan pukul 16.00 WIT, sedangkan untuk 3 kali pemberian diberikan pada : pukul 07.00 WIT, pukul 13.00 WIT dan pukul 18.00 WIT.

\section{Metode Pengumpulan Data}

Pengukuran pertumbuhan ikan Beronang dilakukan setiap 30 hari (sebulan) sekali. Pengukuran setiap bulan sekali dimaksudkan untuk menghindari stress akibat perlakuan yang secara terus menerus (Khairuman dan Rochdianto, 2002). Parameter yang diamati untuk pengambilan data antara lain : pengukuran laju pertumbuhan mutlak (GR), laju pertumbuhan spesifik (SGR), tingkat kelangsungan hidup (SR), efisiensi penggunaan pakan dan kualitas air ( salinitas, suhu, $\mathrm{pH}$, oksigen terlarut, dan amonia). Untuk pengumpulan data dilakukan Pengukuran dan penimbangan pertumbuhan panjang dan berat ikan beronang pada setiap 30 hari sekali untuk mendapatkan ukuran panjang dan berat yang akurat.

Sedangkan kelangsungan hidup diperoleh setelah akhir masa pemeliharaan dengan menghitung jumlah ikan yang hidup. Pengambilan data kualitas air (suhu, salinitas, oksigen terlarut, $\mathrm{pH}$ dan amonia) dilakukan dua minggu sekali. 
Naiboki Salampessy dan Irawati. Laju Pertumbuhan Dan Kelangsungan Hidup Ikan Baronang Siganus canalicalatus Yang DiberiJenis Pakan dan Frekuensi Yang Berbeda di Keramba Jaring Apung

\section{Analisis Data}

Analisis Sidik Ragam (ANOVA)

Sebelum dilakukan Analisis Sidik Ragam, data diuji kenormalan nya dengan menggunakan Uji Harley $F_{\max }$ (Sokal \& Rolf, 1990). Jika data tidak normal (heterogen) maka dilakukan transformasi (Log X+1). Selanjutnya data pertumbuhan dianalisis dengan menggunakan Rancangan Acak Lengkap (Two-Way ANOVA) untuk menguji hipotesis perbedaan peningkatan pertumbuhan dan kelangsungan hidup ikan Beronang dengan jenis pemberian pakan yang berbeda.

Analisis Pertumbuhan Ikan Beronang

a. Analisis Laju Pertumbuhan Mutlak

Analisis laju pertumbuhan mutlak didapat dari selisih antara berat rerata akhir dikurangi dengan berat rerata awal, dan panjang rerata akhir dikurangi panjang rerata awal yang dalam rumus sebagai berikut (Zonneveld et.al.,1991):

$\mathrm{W}=\mathrm{wt}-\mathrm{w} 0$ dan $\mathrm{L}=\mathrm{Lt}-\mathrm{L} 0$

\begin{tabular}{|c|c|c|c|}
\hline \multirow[t]{6}{*}{ Dimana, } & W & $=$ & Pertambahan Bobot \\
\hline & $\mathrm{Wt}$ & $=$ & Berat rerata akhir \\
\hline & W0 & $=$ & Berat rerata awal \\
\hline & $\mathrm{L}$ & $=$ & Pertumbuhan Panjan \\
\hline & $\mathrm{Lt}$ & $=$ & Panjang rerata akhir \\
\hline & L0 & $=$ & Panjang rerata awal \\
\hline
\end{tabular}

b. Analisis Laju Pertumbuhan Spesifik

Laju pertumbuhan spesifik (LPS) yaitu pertumbuhan panjang setiap harinya dihitung dengan persamaan yang dikemukakan oleh Wehatherley \& Roger (1987) dalam Syandri (1996) yaitu :

$$
\begin{array}{cll}
\mathrm{G}= & \frac{\log \mathrm{L} 2-\log \mathrm{L} 1}{\mathrm{~T}} \\
\text { Dimana : } & \\
\mathrm{G}= & \text { Laju pertumbuhan panjang spesifik } \\
\mathrm{L} 2= & \text { Panjang rerata pada akhir pengamatan }(\mathrm{cm}) \\
\mathrm{L} 1= & \text { Panjang rerata pada awal pengamatan } \\
\mathrm{T} & = & \text { Lama waktu antara akhir pengamatan dan awal Pengamatan (hari) }
\end{array}
$$

Analisis Kelangsungan Hidup

a. Tingkat kelangsungan hidup (Survival rate) yaitu persentase jumlah ikan yang hidup setelah penelitian terhadap jumlah ikan awal penelitian. Kelangsungan hidup ikan selama penelitian dihitung berdasarkan metode yang dikemukakan oleh Chapman dalam Anonim (2003) sebagai berikut :

$$
\mathrm{SR}=\frac{\mathrm{Nt}}{\mathrm{No}} \times 100 \%
$$

Keterangan :

$$
\begin{array}{cll}
\mathrm{SR} & = & \text { Kelangsungan hidup } \\
\mathrm{N} 0 & = & \text { Jumlah ikan awal pemeliharaan } \\
\mathrm{Nt} & = & \text { Jumlah ikan akhir pemeliharaan }
\end{array}
$$

b. Efisiensi penggunaan pakan

Efisiensi pakan adalah bobot basah daging ikan yang diperoleh per satuan berat kering pakan yang diberikan. Hal ini sangat berguna untuk membandingkan nilai pakan yang mendukung pertambahan bobot. Efisien pakan berubah sejalan dengan tingkat pemberian pakan dan ukuran ikan. Efisiensi pakan dipengaruhi oleh beberapa faktor diantaranya kualitas pakan, jumlah pakan, spesies ikan, ukuran ikan dan kualitas air. Rumus yang digunakan untuk menghitung efisiensi pakan menurut Afrianto dan Evi (2005) sebagai berikut :

$$
\begin{aligned}
\mathrm{EP}=\frac{F}{W t+D)-(W o)} \times & 100 \% \\
\text { Keterangan }: \mathrm{EP} & =\text { Efisiensi pakan }(\%) \\
\mathrm{Wt} & =\text { Bobot ikan akhir }(\mathrm{g}) \\
\mathrm{Wo} & =\text { Bobot ikan awal }(\mathrm{g}) \\
\mathrm{D} & =\text { Bobot ikan mati }(\mathrm{g}) \\
\mathrm{F} & =\text { Jumlah pakan dikonsumsi }(\mathrm{g})
\end{aligned}
$$

Kualitas Air

Untuk mendorong pertumbuhan dan kelangsungan hidup benih ikan sangat ditentukan oleh kualitas air yang optimal, kualitas air yang baik akan mendukung kesehatan dan pertumbuhan ikan Beronang di keramba jaring apung, sehingga pengukuran parameter kualitas air perlu diamati meliputi parameter fisika yaitu suhu dan parameter 
Naiboki Salampessy dan Irawati. Laju Pertumbuhan Dan Kelangsungan Hidup Ikan Baronang Siganus canalicalatus Yang DiberiJenis Pakan dan Frekuensi Yang Berbeda di Keramba Jaring Apung

kimia yaitu salinitas, oksigen terlarut, $\mathrm{pH}$ dan amonia. Pengecekan parameter kualitas air dilakukan setiap 2 minggu sekali.

\section{HASIL DAN PEMBAHASAN}

\section{Laju Pertumbuhan Mutlak}

Hasil analisis sidik ragam perlakuan, yaitu pemberian jenis dan frekuensi pakan yang berbeda menunjukkan bahwa tidak memberikan pengaruh berbeda terhadap pertumbuhan panjang ikan Beronang Siganus canaliculatus $(\mathrm{P}>0,05)$. Hal ini menunjukkan bahwa pemberian jenis dan frekuensi pakan yang berbeda selama periode pengamatan secara faktual menunjukkan adanya perbedaan namun secara statistik tidak mempengaruhi pertumbuhan panjang mutlak. Pertumbuhan mutlak panjang tertinggi terjadi pada perlakuan p2f3 (pakan 50\% rucah dan 50\% daun papaya) sebesar 7,48 cm, selain kontrol atau tanpa perlakuan seperti tampak pada Gambar 2.

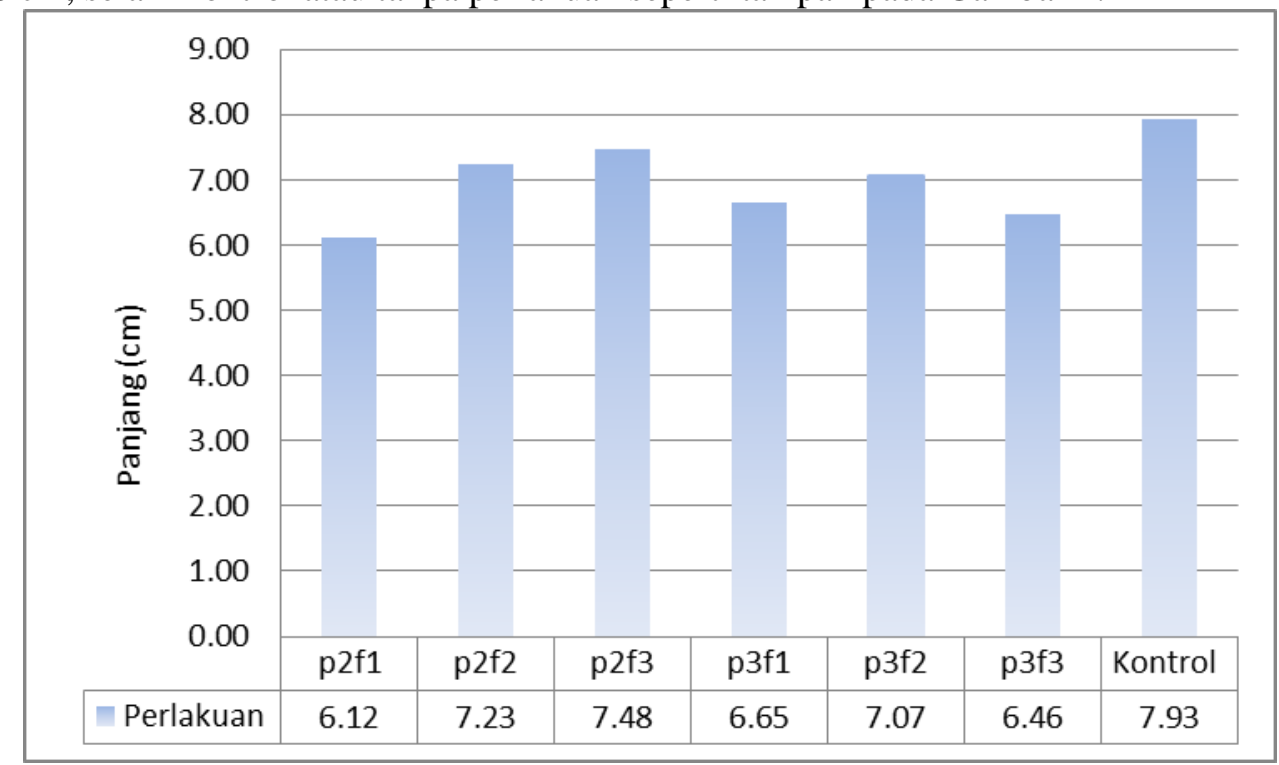

Gambar 2. Grafik laju pertumbuhan mutlak panjang ikan Beronang selama pemeliharaan 120 hari (P : jenis pakan, $\mathrm{f}$ : frekuensi pemberian)

Hasil penelitian ini menunjukkan bahwa berdasarkan data laju pertumbuhan panjang tebar awal pada masing-masing perlakuan terdapat perbedaan sebesar $1 \mathrm{~cm}$, yakni pada : perlakuan p2f1 $(12,12 \mathrm{~cm})$, p2f2 $(11,24$ $\mathrm{cm}), \mathrm{p} 2 \mathrm{f} 3(12,05 \mathrm{~cm}), \mathrm{p} 3 \mathrm{f} 1(12,62 \mathrm{~cm}), \mathrm{p} 3 \mathrm{f} 2(11,40 \mathrm{~cm})$ dan p3f3 $(12,22 \mathrm{~cm})$. Setelah pemeliharaan selama 1 bulan, dilakukan pengukuran ke 2 diperoleh hasil selisih pengukuran ke dua dan ke satu tertinggi terdapat pada perlakuan p2f3 sebesar 2,83 cm, sedangkan yang terendah terdapat pada perlakuan p2f1 sebesar 2,2 cm. Pada pengukuran ke tiga, diperoleh selisih pertumbuhan dengan ukuran pada bulan ke dua dengan nilai tertinggi terdapat perlakuan p3f1 sebesar 2,80 cm dan terendah pada perlakuan p2f1 sebesar 1,78 cm (Lampiran 14).

Secara umum nilai pertumbuhan panjang mutlak tertinggi pada penelitian ini terjadi pada kontrol $(7,93 \mathrm{~cm})$. Untuk perlakuan yang diaplikasikan, nilai pertumbuhan panjang mutlak tertinggi terjadi pada perlakuan p2f3 $(7,48$ $\mathrm{cm})$ dan nilai terendah terjadi pada perlakuan p2f1 $(6,12 \mathrm{~cm})$. Hasil pertumbuhan mutlak panjang memiliki korelasi dengan hasil pertumbuhan berat mutlak dengan nilai tertinggi pada perlakuan yang sama yakni p2f3. Pertumbuhan ikan bersifat isometric menunjukkan bahwa adanya keseimbangan antara pertambahan panjang dan berat ikan. Hal ini menunjukkan hubungan koefisien korelasi antara variabel panjang dan berat memiliki hubungan yang kuat atau adanya hubungan antara panjang dan berat ikan (Irianto, 2010).

Dalam penelitian ini, terlihat bahwa pakan pellet dengan kandungan protein yang tinggi $(52,59 \%)$ sebagai kontrol memberikan pertumbuhan terbaik dibandingkan dengan 6 perlakuan yang diaplikasikan. Namun perbedaan nilainya tidak terlalu signifikan hal ini diduga peningkatan jumlah protein dalam pakan akan meningkatkan pertumbuhan sampai batas tertentu (benih). Prather \& Lovell (1973) dalam Samantaray \& Mohanty (1997) menjelaskan bahwa kandungan protein pakan yang tinggi akan berpengaruh buruk terhadap pertumbuhan ikan jika tidak diimbangi kandungan energi yang cukup. Selanjutnya Lovell (1989) mengemukakan bahwa tinggi rendahnya kebutuhan optimum protein dalam pakan ikut dipengaruhi oleh kandungan energi dari non-protein (karbohidrat dan lemak).

Selain itu diduga pula, perbedaan hasil pertumbuhan panjang maupun berat mutlak yang tidak signifikan karena kandungan protein yang dimiliki masing-masing jenis pakan perlakuan selain kontrol optimal dalam 
Naiboki Salampessy dan Irawati. Laju Pertumbuhan Dan Kelangsungan Hidup Ikan Baronang Siganus canalicalatus Yang DiberiJenis Pakan dan Frekuensi Yang Berbeda di Keramba Jaring Apung

pertumbuhan sebagaimana yang tertera pada grafik sedangkan pada kontrol dengan kandungan protein yang nilainya tiga kali lipat, banyak dimanfaatkan sebagai sumber energy.

Hal ini berhubungan dengan pendapat yang mengatakan protein juga banyak digunakan sebagai sumber energi bagi hewan air, khususnya ikan herbivore (NRC, 1977). Kebutuhan energi ikan tropis telah dilaporkan merupakan fungsi dari kandungan protein dalam pakan (NRC, 1983).

Berkaitan dengan hasil pemeriksaan kandungan proximate bahan baku pakan uji kedua jenis pakan tersebut dan hasil prediksi kandungan proximate masing-masing pakan uji, kandungan protein pada pakan uji p2 (50\% rucah $\& 50 \%$ daun pepaya) memiliki kandungan protein lebih tinggi yakni adalah $14,81 \%$ dari perlakuan p3 (25\% rucah \& $75 \%$ daun pepaya) adalah $11,20 \%$ (Tabel 10) Kandungan protein diperoleh dari 2 bahan pakan yakni protein nabati dari daun pepaya dan protein hewani dari ikan rucah. Menurut Fauzi et al (2008) kandungan protein ikan rucah berkisar antara 51,13-70,05\%.

Menurut Watanabe (1988), pertumbuhan ikan sangat erat kaitannya dengan ketersediaan protein dalam pakan. Protein adalah nutrisi penting dalam pakan ikan (De Silva et al, 1987). Protein berfungsi sebagai komponen struktural penyusun sel dan jaringan tubuh baru untuk pertumbuhan. Kualitas protein pakan, terutama ditentukan oleh kandungan asam amino esensial nya, semakin rendah kandungan asam amino esensial nya maka mutu protein semakin rendah (Indah, 2007).

Menurut Hasting (1976) menyatakan bahwa kandungan nutrisi yang baik untuk ikan secara umum adalah mulai dari $20-60 \%$ protein, 4-8\% lemak dan karbohidrat sampai 30\%. Sedangkan menurut Masyamsir (2001) kandungan nutrisi yang dibutuhkan untuk ikan Beronang yakni 15-20\% protein, 8\% lemak dan 15\% karbohidrat.

Adanya kandungan daun pepaya dalam pakan yang digunakan dalam semua perlakuan memilki nilai pertumbuhan berat dan panjang yang optimal. Muchtadi et al (1992) menyatakan bahwa papain (enzim yang terkandung dalam daun papaya) merupakan enzim proteolitik yang mampu memecah struktur kompleks protein menjadi struktur yang lebih sederhana dan Amalia et al (2013) menyatakan bahwa papain dalam pakan mampu meningkatkan efisiensi pakan, rasio efisiensi protein dan laju pertumbuhan ikan lele Dumbo.

Penelitian yang telah dilakukan Hasan (2000), bahwa enzim papain mampu meningkatkan laju pertumbuhan, efisiensi pakan pada benih ikan gurami, dan juga menurut Fadli (2013) pada ikan kerapu macan, namun menurut Jobling et al. (2001) mengemukakan bahwa penggunaan sumber protein nabati sebagai bahan utama dalam pakan ikan akan mengakibatkan kekurangan satu atau lebih asam amino esensial yang dibutuhkan oleh ikan. Dari hasil analisis asam amino pakan uji terlihat bahwa semakin rendah kandungan protein dalam pakan semakin rendah pula total asam amino yang dikandungnya (Tabel 3). Asam amino dibutuhkan oleh ikan untuk pertumbuhan dan mempertahankan proses metabolisme tubuh (maintenance) (Cowey, 1994). Hal ini menjelaskan bahwa pemberian protein nabati saja tidak dapat memberikan pertumbuhan yang baik bagi ikan beronang walaupun ikan beronang termasuk jenis ikan herbivor. Seperti jenis ikan lainnya ikan beronang membutuhkan keseimbangan protein hewani dan nabati dalam pakannya untuk memenuhi kebutuhan asam amino esensial yang dapat menunjang pertumbuhannya. Faktor eksternal lainnya yang diduga menjadi pemicu tingginya pertumbuhan mutlak panjang pada perlakuan p3f1 yakni faktor genetik, dan kualitas air.

Terkait dengan frekuensi pemberian pakan budidaya ikan sangat dipengaruhi oleh pencernaan nya. Frekuensi pemberian pakan yang lebih sering, diduga akan lebih baik karena pada saat pencernaan ikan mulai kosong, ikan harus segera memperoleh makanan kembali dan pemberian pakan dalam jumlah kecil dan sering ini akan memberikan kesempatan proses metabolisme makanan dalam saluran pencernaan untuk bekerja dengan baik sehingga pakan yang dimakan dapat ter absorbsi maksimal untuk pertumbuhan dan menjadi energi. Selain itu makanan yang diberikan juga tidak tersisa atau tidak ada pakan yang terbuang. Menurut Gwiter dan Grove (1981), semakin kecil kapasitas lambung semakin cepat waktu pengosongan lambung sehingga frekuensi pemberian pakan yang dibutuhkan lebih sering. Ishak (2001) menyatakan bahwa Siganidae merupakan ikan herbivore, sedangkan ikan herbivor panjang usus beberapa kali lipat dari panjang tubuhnya dibandingkan pada ikan karnivora, keadaan usus yang sangat panjang pada ikan herbivor merupakan kompensasi terhadap kondisi makanan yang memiliki kadar serat yang tinggi sehingga memerlukan pencernaan lebih lama. Usus yang panjang tersebut bertujuan untuk mendapatkan hasil pencernaan makanan secara maksimal.

\section{Pertumbuhan Berat Mutlak}

Uji statistik laju pertumbuhan berat mutlak ikan beronang Siganus canaliculatus menunjukkan tidak adanya perbedaan $(p>0,05)$. Hal ini menunjukkan bahwa pemberian jenis dan frekuensi pakan yang berbeda selama periode pengamatan secara faktual menunjukkan adanya perbedaan namun secara statistik tidak mempengaruhi pertumbuhan berat.

Hasil statistik ini sesuai dengan yang dikemukakan Robinson, et al, 1995 dan Jarboe dan Grant, 1996) yang melaporkan dalam penelitiannya bahwa waktu dan frekuensi pemberian pakan tidak signifikan mempengaruhi 
penambahan berat badan, konsumsi pakan, FCR dan SR dalam satu ukuran unit produksi ikan lele. Data pertumbuhan berat rata-rata pada semua perlakuan selama penelitian dapat dilihat pada Gambar 6.

Sedangkan grafik berat rata-rata pertumbuhan mutlak dapat dilihat pada Gambar 3

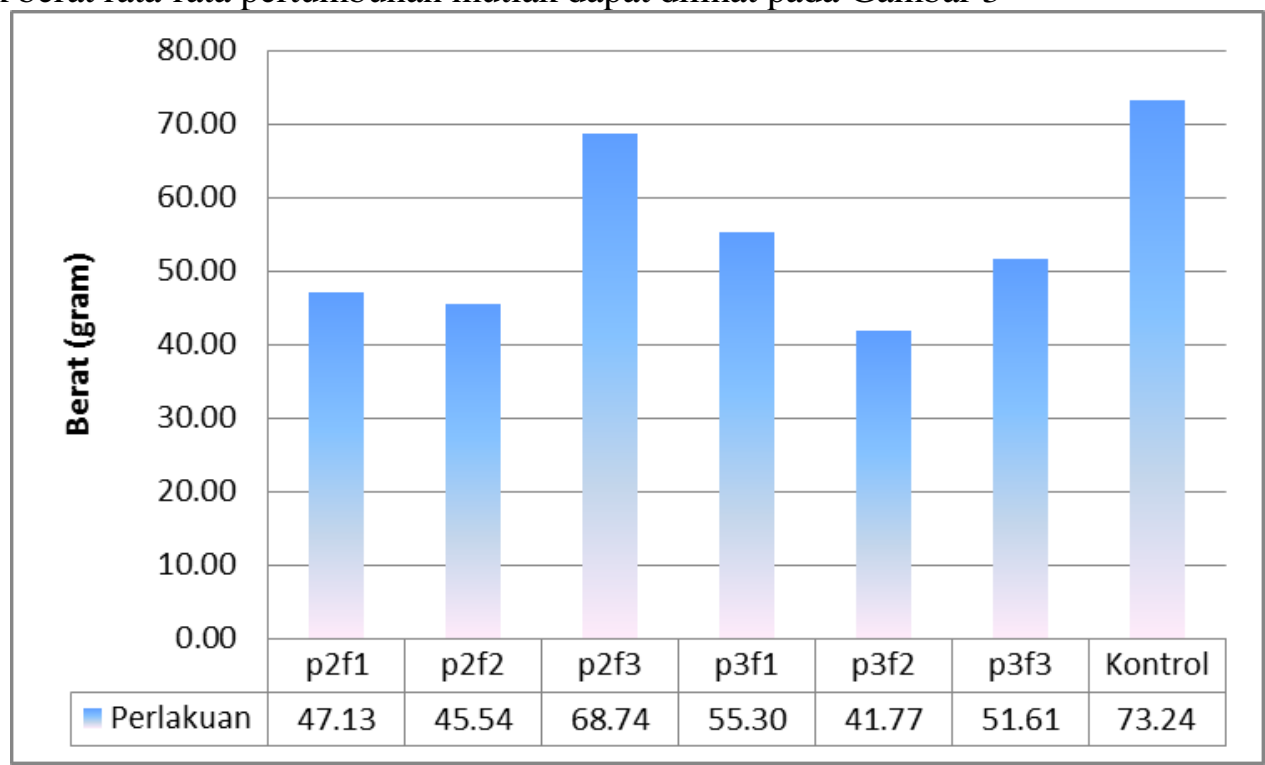

Gambar 3. Grafik laju pertumbuhan berat mutlak ikan Beronang pemeliharaan selama 120 hari

Secara umum pertumbuhan tertinggi terdapat pada kontrol $(73,24)$ yang menggunakan pakan pellet dengan pemberian pakan 2 kali. Untuk nilai tertinggi pada 6 perlakuan yang diaplikasikan, nilai pertumbuhan berat mutlak tertinggi terdapat pada perlakuan p2f3 $(68,74)$. Tingginya nilai pertumbuhan mutlak pada perlakuan p2f3 diduga karena pada perlakuan ini diberikan pakan dengan komposisi 50\% ikan rucah dan 50\% daun pepaya dan frekuensi pemberiannya lebih sering. Di bandingkan dengan komposisi pakan dengan dosis daun pepaya yang lebih banyak, pada dosis pakan yang mengandung daun pepaya sedikit (50\%) lebih diminati ikan hal ini disebabkan tingginya dosis serbuk daun pepaya yang menyebabkan nafsu makan ikan menurun. Tingginya dosis yang digunakan justru berpengaruh pada rasa pakan dihasilkan. Daun pepaya mengandung flavonoid dengan bau dan rasa khas. Pemberian dosis serbuk daun pepaya yang tinggi menyebabkan rasa menjadi pahit pada ikan. (Austin, 1993). Rasa yang pahit menyebabkan ikan kurang merespon pakan yang diberikan sehingga menurunkan konsumsi pakan dan berpengaruh pada kelangsungan hidup. Sebaliknya, beberapa penelitian melaporkan bahwa waktu pemberian pakan dan frekuensi pemberian pakan tidak berpengaruh nyata terhadap pertambahan bobot badan, konsumsi pakan, rasio konversi pakan (FCR) dan kelangsungan hidup pada unit produksi lele ukuran tunggal. (Rolanson, et,al, 1995).

Terkait dengan frekuensi pemberian pakan 3 kali yang memberikan pertumbuhan terbaik dari hasil penelitian ini, hal ini diduga terjadi karena jumlah pakan yang diberikan mendekati kapasitas tampung lambung ikan sehingga pakan yang diberikan dapat dikonsumsi dan dicerna dengan sempurna oleh ikan. Pemberian pakan dengan jumlah sama dengan frekuensi yang lebih sering, menghasilkan efek pertumbuhan yang baik pada ikan karena dapat memberikan waktu untuk mengolah makan tersebut dalam pencernaan secara maksimal sehingga dapat terserap dengan baik untuk meningkatkan pertumbuhan. Hal ini sesuai dengan yang dikemukakan oleh Barakat et,al, (2011) dalam penelitiannya bahwa pemberian pakan pada ikan beronang dengan frekuensi 3 kali sehari lebih baik dibanding dengan pemberian pakan 1 kali atau 2 kali. Selain itu pemberian pakan 3 kali sehari dapat meningkatkan struktur dan kualitas daging.

Menurut Gwiter dan Grove (1981), semakin kecil kapasitas lambung semakin cepat waktu pengosongan lambung sehingga frekuensi pemberian pakan yang dibutuhkan lebih sering. Ikan yang diberi pakan hanya 1 atau 2 kali akan mengalami lapar terlalu lama sehingga pada saat pakan diberikan, lambung ikan akan kosong dan nafsu makan semakin tinggi. Dalam keadaan seperti ini, cenderung untuk mengkonsumsi pakan sebanyak-banyaknya sehingga isi lambung mencapai maksimum. Selanjutnya kondisi ini menyebabkan proses pencernaan pakan yang terjadi tidak berjalan sempurna. Hal ini disebabkan pencampuran enzim pencernaan dengan pakan tidak merata. Hieking (1971) menyatakan bahwa pakan yang tercampur dengan enzim dapat tercerna dengan baik, sedangkan yang tidak akan dikeluarkan sebagai kotoran. Oleh karena itu, energy yang dihasilkan relative lebih rendah dibandingkan yang dicerna secara sempurna. Hal ini sama dengan yang dinyatakan NRC (1977) bahwa pakan diberikan dalam jumlah terlalu banyak menyebabkan pakan tidak termanfaatkan secara efisien. Kono dan Nose dalam Tawulo (2004), menyatakan bahwa variasi frekuensi pemberian pakan diduga berhubungan erat dengan kapasitas lambung. 
Budidaya ikan beronang dalam keramba jaring apung sepenuhnya mengandalkan pakan buatan. Jumlah pakan yang diberikan yakni $4 \%$ dari total berat ikan / hari, pemberian pakan dilakukan pada pagi, siang dan sore hari, pemberian pakan dilakukan sedikit demi sedikit. Hal ini dilakukan agar pakan tidak banyak terbuang, karena pada saat pemberian pakan ikan beronang sangat aktif bergerak sehingga menimbulkan arus dalam jaring. Menurut Rachmansyah (1993), bahwa pemberian pakan yang sembrono dan tergesa-gesa akan menyebabkan 5 - $10 \%$ pakan yang diberikan akan terbuang keluar.

Pertumbuhan terendah terjadi pada perlakuan, p3f2 (perlakuan jenis pakan 25\% ikan rucah dan $75 \%$ daun papaya) yakni 41,77 . Rendahnya pertumbuhan mutlak pada perlakuan ini, diduga berhubungan dengan perbedaan nilai protein yang terkandung pada kedua jenis pakan yang digunakan. Sesuai dengan hasil uji proximate pada bahan baku pakan uji, dimana ikan rucah mengandung 22, $02 \%$ dan daun pepaya 7,60\%, dan hasil analisis kandungan proximate pada masing-masing perlakukan (Tabel 9) yaitu kandungan protein pada perlakuan p2:14,81\% dan p3 : $11,20 \%$, hal ini di perkuat dengan pendapat Hasting (1976), menyatakan bahwa Kandungan nutrisi yang baik untuk ikan secara umum adalah mulai dari 20-60\% protein, 4-8\% lemak dan karbohidrat sampai 30\% (Hasting, 1976). Sedangkan menurut Masyamsir (2001) kandungan nutrisi yang dibutuhkan untuk ikan Beronang yakni 15-20\% protein, $8 \%$ lemak dan $15 \%$ karbohidrat

Komposisi pakan pada perlakuan jenis $25 \%$ ikan rucah dan $75 \%$ daun pepaya didominasi oleh protein nabati sehingga menghasilkan pertumbuhan ikan beronang yang rendah. Hal ini menjelaskan bahwa pemberian protein nabati saja tidak dapat memberikan pertumbuhan yang baik bagi ikan beronang walaupun ikan Beronang termasuk jenis ikan herbivor. Seperti jenis ikan lainnya ikan Beronang membutuhkan keseimbangan protein hewani dan nabati dalam pakannya untuk memenuhi kebutuhan asam amino esensial yang dapat menunjang pertumbuhannya. Jobling et al. (2001) mengemukakan bahwa penggunaan sumber protein nabati sebagai bahan utama dalam pakan ikan akan mengakibatkan kekurangan satu atau lebih asam amino esensial yang dibutuhkan oleh ikan. Dari hasil analisis asam amino pakan uji terlihat bahwa semakin rendah kandungan protein dalam pakan semakin rendah pula total asam amino yang dikandungnya (Tabel 3). Asam amino dibutuhkan oleh ikan untuk pertumbuhan dan mempertahankan proses metabolisme tubuh (maintenance) (Cowey, 1994).

\section{Pertumbuhan Spesifik}

Berdasarkan hasil pengamatan pertumbuhan selama 120 hari, maka pertumbuhan spesifik rata-rata dari panjang ikan beronang Siganus canaliculatus pada pelakuan p2f1, p2f2,p2f3,p3f1,p3f2,p3f3 dan kontrol disajikan pada Gambar 4.

Berdasarkan hasil analisis variansi (ANOVA) (Lampiran 3), pertumbuhan spesifik panjang ikan, didapatkan $\mathrm{F}$ hitung lebih kecil daripada $\mathrm{F}$ table, hal ini berarti antar perlakuan menunjukkan tidak adanya perbedaan pertumbuhan panjang spesifik.

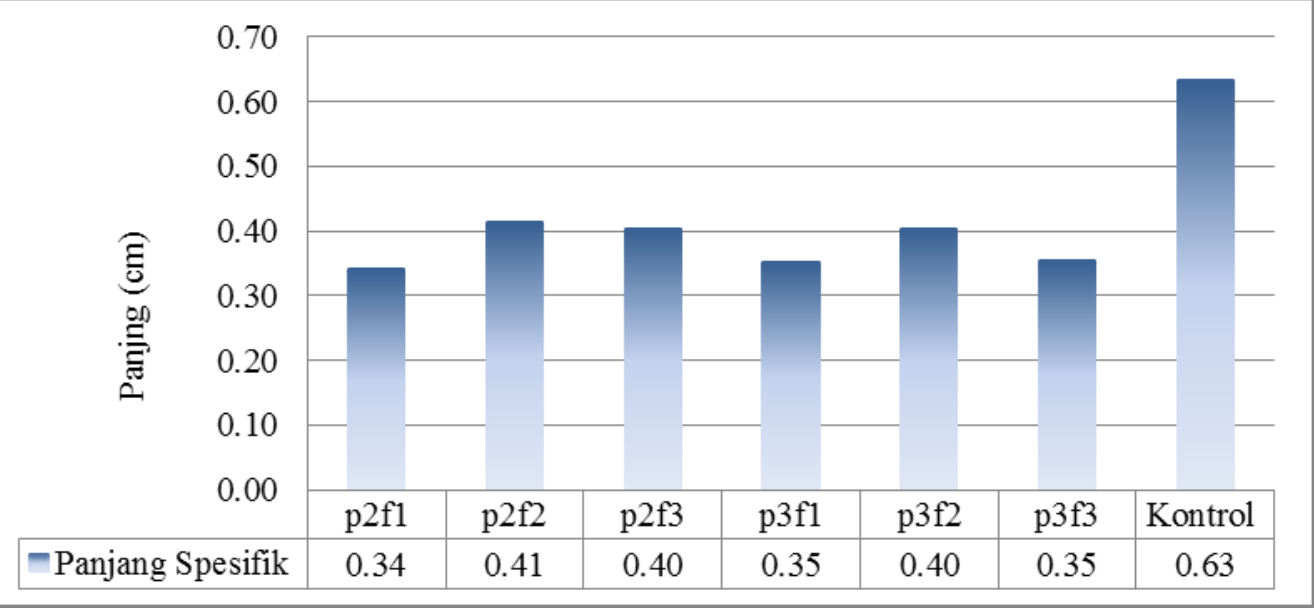

Gambar 4. Grafik pertumbuhan panjang spesifik ikan Beronang pemeliharaan selama 120 hari

Laju pertumbuhan panjang spesifik tertinggi terdapat pada perlakuan kontrol yakni menggunakan pakan pellet komersial, kemudian pada perlakuan p3f1 (komposisi pakan 25\% ikan rucah $75 \%$ daun pepaya dengan frekuensi pemberian 1 kali sehari) sebesar $0,44 \mathrm{~cm}$, sedangkan laju pertumbuhan panjang terendah terdapat pada perlakuan p2f1(komposisi pakan 50\% ikan rucah 50\% daun pepaya dengan frekuensi pemberian 1 kali sehari) 0,34 $\mathrm{cm}$. Berbeda dengan hasil yang diperoleh pada pertumbuhan berat mutlak dimana perlakuan $\mathrm{p} 2 \mathrm{f} 3$ yang memberikan pertumbuhan tertinggi, namun pada hasil pertumbuhan panjang spesifik ini nilai tertinggi terdapat pada perlakuan p3fi. Hal ini memperkuat hasil dari analisis statistik pada semua perlakuan terhadap parameter yang diuji dimana pada semua parameter, 6 perlakuan yang diuji coba kan pada hewan uji memperlihatkan bahwa tidak terdapat 
pengaruh baik faktor jenis pakan maupun frekuensi. Selain faktor internal dari perlakuan yang diberikan (jenis pakan dan frekuensi pemberian), terjadinya perbedaan pertumbuhan di duga diakibatkan oleh perbedaan ukuran panjang awal pada saat ditebar, dimana pada perlakuan p3f1 memiliki ukuran awal tebar lebih panjang dari perlakuan lainnya.

Pertumbuhan ikan dipengaruhi oleh dua faktor yaitu faktor dalam dan faktor luar. Faktor dalam umumnya adalah faktor yang sukar dikontrol seperti sifat genetic, umur dan jenis kelamin. Sedangkan faktor luar adalah makanan dan kualitas perairan.

Dalam penelitian ini, dosis pakan yang diberikan adalah sama atau homogen yaitu $4 \%$ dari bobot tubuh ikan beronang. Hal tersebut sesuai dengan pernyataan Liviawaty dan Afrianto (2005) yang menyatakan bahwa jumlah pakan yang umum diberikan pada ikan adalah 3-5\% dari bobot tubuh. Pertumbuhan akan semakin cepat, jika makanan diberikan sesuai dengan kebutuhan ikan, sedangkan jika pakan diberikan secara berlebihan ke dalam wadah pemeliharaan akan mengakibatkan pemborosan dan penurunan kualitas air.

Sesuai dengan hasil penelitian yang dilakukan untuk Rosle. S, 1995 penebaran awal dengan berat rata-rata 10,5 gr. Pertumbuhan tajam pada berat ikan, terjadi pada bulan ke 3. Pertumbuhan luar biasa pada ikan beronang pada penelitian tergantung dengan kandungan protein pakan, management pengelolaan pakan yang layak, kualitas air, kesesuaian wadah pemeliharaan dan kelayakan penanganan selama pemeliharaan. Soletehhik (1984) melaporkan bahwa juvenil dr. S. Guttatus menumbuhkan 33\% protein. Gerochi et al (1988 b) menemukan bahwa 25\% protein memberikan sebagai diet supplement. Para (1989) menemukan bahwa pertumbuhan spesifik. S. Guttatus meningkat sering dengan keuntungan protein dan 10 level energy. Hal ini menitikberatkan bahwa 35\% protein akan lebih ekonomis.

Menurut Hasting (1976), menyatakan bahwa Kandungan nutrisi yang baik untuk ikan secara umum adalah mulai dari 20-60\% protein, 4-8\% lemak dan karbohidrat sampai 30\% (Hasting, 1976). Sedangkan menurut Masyamsir (2001) kandungan nutrisi yang dibutuhkan untuk ikan Beronang yakni 15-20\% protein, 8\% lemak dan $15 \%$ karbohidrat.

Hasil uji statistik menunjukkan tidak adanya perbedaan nyata $(\mathrm{p}>0,05)$ antara semua perlakuan terhadap laju pertumbuhan berat spesifik ikan beronang yang dipelihara selama 120 hari. Namun secara faktual, terlihat adanya perbedaan pertumbuhan. Perbedaan tersebut berkisar $0,1 \mathrm{~cm}$. Pertumbuhan spesifik berat dari ikan beronang berdasarkan hasil penelitian ini terlihat pada Gambar 5.

Rata-rata laju pertumbuhan tertinggi terdapat pada perlakuan p2f3 sedangkan terendah terdapat pada p3f2.

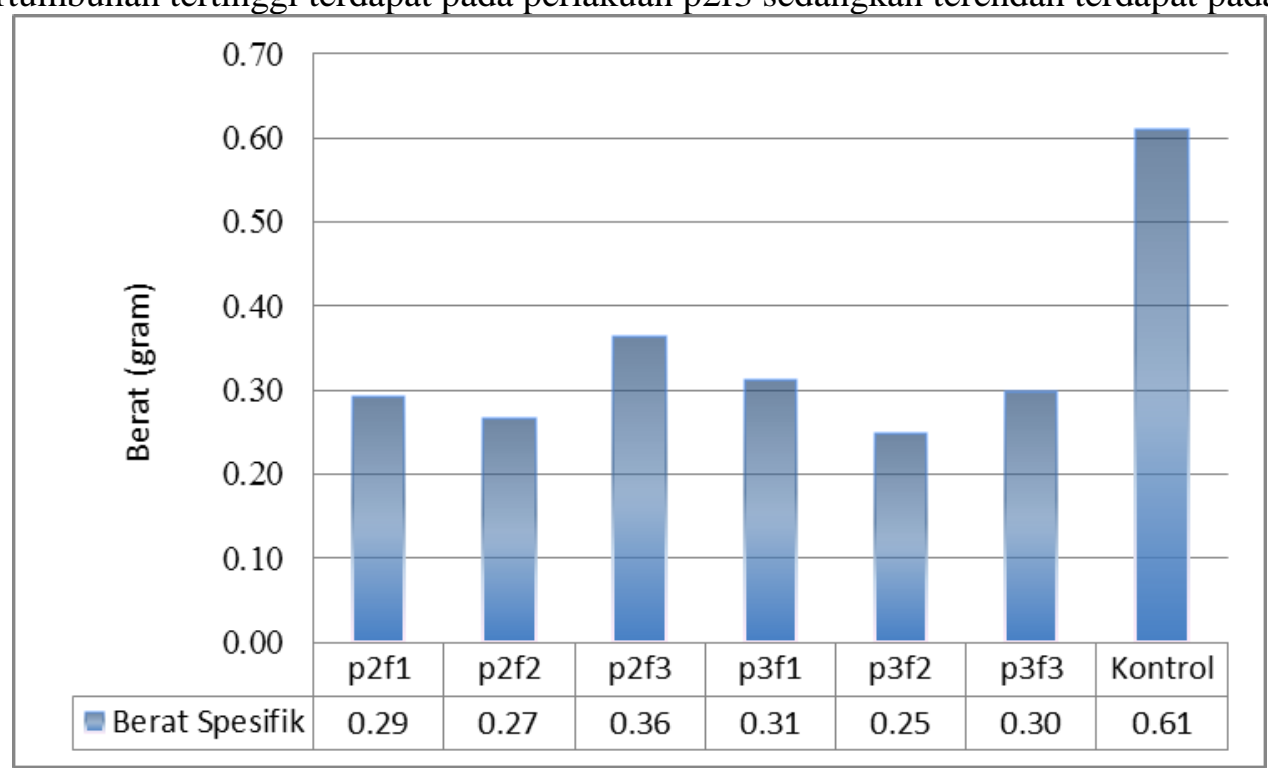

Gambar 5. Data pertumbuhan berat spesifik ikan Beronang pemeliharaan selama 120 hari

Hasil pertumbuhan berat spesifik ikan beronang, selaras dengan hasil pertumbuhan berat mutlak dimana pertumbuhan tertinggi terdapat pada perlakuan kontrol, kemudian disusul pada perlakuan $\mathrm{p} 2 \mathrm{f} 3$ dan terendah pada p3f2. Oleh karena itu, diduga faktor pemberian pakan dengan frekuensi yang lebih sering dan dosis pakan yang menggunakan pakan rucah 50\% dan 50\% daun pepaya memiliki dampak yang lebih baik terhadap laju pertumbuhan spesifik ikan beronang. Perlakuan p2f3 memberikan pertumbuhan mutlak terbaik, juga didukung oleh hasil dari penelitian terdahulu Diana R, dkk, 2016 tentang aplikasi enzim papain dalam pakan buatan sebagai pemacu pertumbuhan upaya percepatan produksi lele Sangkuriang. Pada penelitian menunjukkan bahwa nilai pertumbuhan spesifik (SGR) ikan lele tertinggi adalah pada perlakuan penggunaan enzim papain 2,25\%/kg pakan (kandungan 
Naiboki Salampessy dan Irawati. Laju Pertumbuhan Dan Kelangsungan Hidup Ikan Baronang Siganus canalicalatus Yang DiberiJenis Pakan dan Frekuensi Yang Berbeda di Keramba Jaring Apung

enzim yang paling rendah pada semua perlakuan). Pada perlakuan jenis pakan dengan dosis $75 \%$ daun pepaya dan $25 \%$ ikan rucah, tidak lebih baik hal diduga karena daun pepaya dalam porsi yang banyak dapat menimbulkan aroma yang kurang sedap yang dapat menurunkan nafsu makan ikan sebagaimana dijelaskan pada pembahasan pertumbuhan mutlak berat ikan.

Berdasarkan uji proximate dari kedua jenis pakan yang digunakan dalam penelitian ini, menunjukan bahwa pakan jenis ikan rucah mengandung protein lebih tinggi dari pada daun pepaya. sehingga kebutuhan protein untuk pertumbuhan ikan beronang terpenuhi dari pakan ikan rucah dan daun pepaya, hal ini diperkuat dengan pendapat Hasting (1976), menyatakan bahwa kandungan nutrisi yang baik untuk ikan secara umum adalah mulai dari 20-60\% protein, 4-8\% lemak dan karbohidrat sampai 30\%. Sedangkan menurut Masyamsir (2001) kandungan nutrisi yang dibutuhkan untuk ikan beronang yakni $15-20 \%$ protein, $8 \%$ lemak dan $15 \%$ karbohidrat. Kandungan proksimat disajikan pada Lampiran 14.

Pakan yang berkualitas adalah pakan yang memiliki kualitas protein yang baik protein yang memiliki kualitas yang tinggi adalah protein yang memiliki kecernaan yang tinggi dan dapat menyediakan semua asam amino esensial. (Hutabarat, 2005). Kebiasaan makanan dan cara memakan ikan secara alami juga tidak terlepas pada lingkungan tempat hidup ikan. Hal ini juga membenarkan apa yang dikatakan oleh Mayunar (2002), bahwa ikan beronang mampu memakan apa saja yang diberikan seperti pakan buatan sesuai dengan morfologi dari gigi dan saluran pencernaan ikan beronang yaitu mulutnya yang kecil, mempunyai gigi seri pada masing-masing rahang, gigi geraham berkembang sempurna, dinding lambung agak tebal, usus halus nya panjang dan mempunyai permukaan yang luas, ikan beronang termasuk pemakan tumbuh-tumbuhan, tetapi kalau dibudidayakan, ikan beronang mampu memakan makanan apa saja yang diberikan seperti pakan buatan, sejalan dengan pendapat M.Ghufran H. Kordi K (2005), menyatakan bahwa dalam pemeliharaan ikan beronang di tambak atau KJA, beronang tidak menolak (memakan) pellet, tepung ikan, cacahan daging ikan dan kerang-kerangan, karena memakan segala jenis makanan inilah, beronang biasa dipancing dengan menggunakan nasi atau pisang.

Meskipun ikan beronang termasuk ikan herbivor, namun menurut Mudjiman (1989), benih ikan yang baru mencari makan, makanan utamanya adalah fitoplankton (nabati) namun sejalan dengan bertambah besarnya ikan maka berubah pula jenis dan pola makanannya, begitu juga dengan ikan beronang. Secara umum kebiasaan makanan yang dimakan (food habit) dipengaruhi oleh kualitas dan kuantitas yang dimakan, sehingga makanan kelimpahan ikan di suatu perairan dipengaruhi dan menentukan pertumbuhan dan kondisi ikan (Effendie, 1997). Dari penelitian yang telah dilakukan pada pemeliharaan ikan selama 120 hari, terlihat kecenderungan perubahan pola makan ikan beronang yamg herbivor ke pola makan yang dapat memakan daging juga hal ini sejalan dengan pendapat Fitrinawati (2004), bahwa perubahan pola makan dari waktu ke waktu diduga dipengaruhi oleh ketersediaan, kelimpahan dan penyebaran sumberdaya makanan yang ada di perairan tersebut.

Kandungan nutrisi bahan pakan yang digunakan dapat mempengaruhi kemampuan ikan untuk menyerap zat yang ada dalam pakan. Serat kasar yang tinggi akan memberikan rasa kenyang karena komposisi karbohidrat kompleks yang menghentikan nafsu makan sehingga mengakibatkan turunnya konsumsi makanan. Kandungan serat kasar pada pakan masih dalam batasan yang normal sehingga ikan dapat dengan mudah mencerna pakan.Keterbatasan ikan dalam memanfaatkan serat berkaitan dengan ketersediaan enzim sellulotik yang terbatas dalam saluran pencernaan ikan, bahkan pada level tertentu dapat menghambat pertumbuhan ikan. Makin tinggi kandungan serat kasar dalam pakan mempengaruhi daya cerna protein yang semakin rendah karena untuk mencerna serat kasar diperlukan banyak waktu dan energi (Cheeke dan Patton, 1980). Ikan beronang dapat dibudidayakan / dipelihara secara intensif dengan menggunakan makan buatan (Bwathondhi,1982, junivio et al, 1985, Hara et al, 1986)

\section{Kelangsungan Hidup}

Kelangsungan hidup merupakan perbandingan antara jumlah individu yang hidup pada akhir percobaan dengan jumlah individu yang hidup pada awal percobaan (Rika,2008). Untuk mempertahankan kelangsungan hidup dan pertumbuhan ikan, maka diperlukan makanan yang memenuhi kebutuhan nutrisi ikan. Makanan yang dimakan oleh ikan digunakan untuk kelangsungan hidup dan selebihnya akan dimanfaatkan untuk pertumbuhan. Hasil pengamatan kelangsungan hidup (SR) pada ikan Beronang yang diberi 6 jenis perlakuan selama 120 hari pemeliharaan.

Uji statistik terhadap Survival Rate (SR) atau kelangsungan hidup ikan Beronang tidak menunjukkan adanya perbedaan yang nyata $(\mathrm{p}>0,05)$ antar perlakuan.

Secara umum, kelangsungan hidup tertinggi terdapat kontol yang mencapai $100 \%$ sedangkan kelangsungan hidup ikan Beronang pada semua perlakuan dalam penelitian ini berada pada kisaran nilai 72,22\% sampai dengan 97,22. Nilai kelangsungan hidup ini masih berada pada kisaran baik. Nilai tingkat kelangsungan hidup ikan rata-rata yang baik berkisar antara 73,5-86,0\%. Menurut Suprayudi et al. (2011), bahwa tingginya kelangsungan hidup menunjukkan kualitas dan kuantitas pakan yang diberikan sudah cukup untuk memenuhi kebutuhan pokok bahkan 
Naiboki Salampessy dan Irawati. Laju Pertumbuhan Dan Kelangsungan Hidup Ikan Baronang Siganus canalicalatus Yang DiberiJenis Pakan dan Frekuensi Yang Berbeda di Keramba Jaring Apung

dapat meningkatkan pertumbuhan. Dua faktor yang dapat mempengaruhi kelulusan hidup, yaitu faktor biotik dan abiotik. Faktor biotik terdiri dari umur dan kemampuan ikan dalam menyesuaikan diri dengan lingkungan tempat hidup. Faktor abiotik antara lain ketersediaan makanan dan kualitas media hidup.

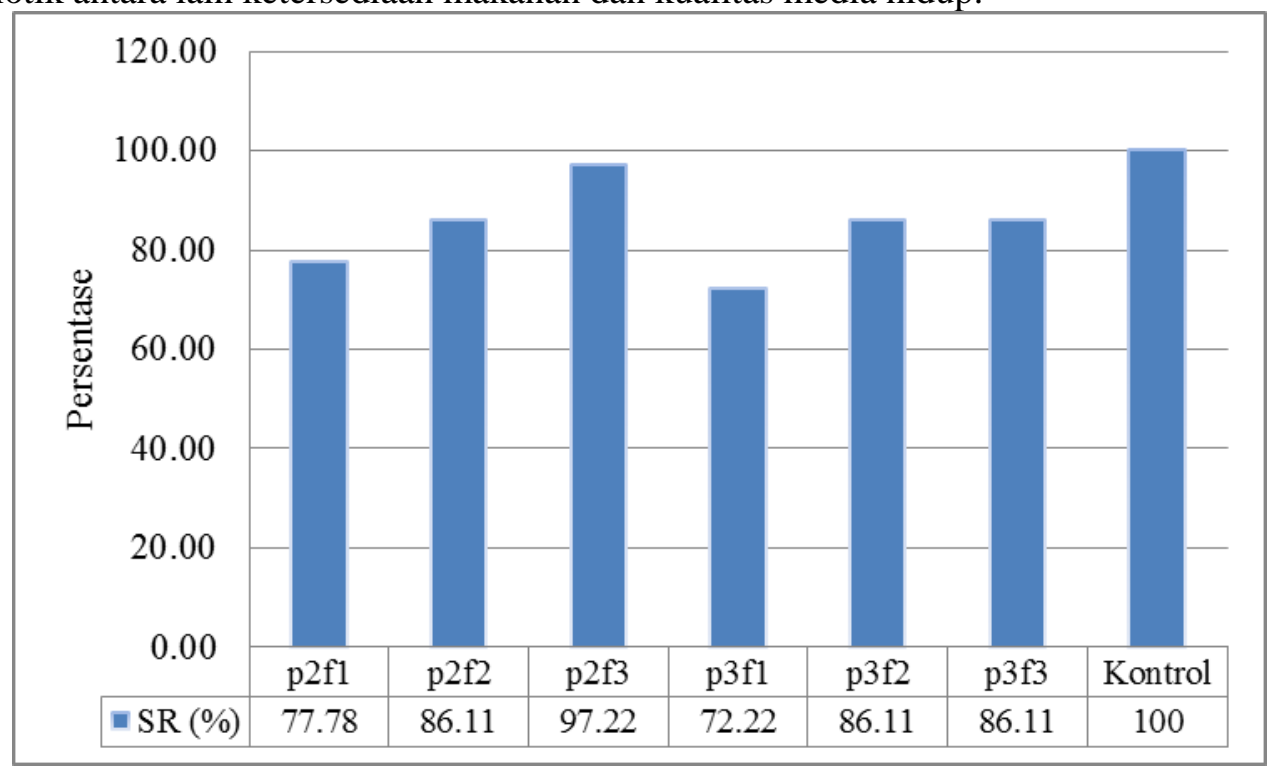

Gambar 6. Grafik kelangsungan hidup ikan Beronang pemeliharaan selama 120 hari

Pada Gambar 6 menunjukkan bahwa secara umum nilai kelangsungan hidup yang tertinggi terdapat pada kontrol (pakan pellet) dan berdasarkan perlakuan, kelangsungan hidup tertinggi terjadi pada perlakuan p2f3 (jenis pakan 50\% daun pepaya 50\% ikan rucah dengan frekuensi pemberian 3 kali), sedangkan secara spesifik pertumbuhan tertinggi terjadi pada perlakukan p2f3 ulangan 2 dan 3 dengan nilai masing-masing $100 \%$. Nilai ratarata kelangsungan hidup terendah terjadi pada perlakuan p3f1 (jenis pakan $75 \%$ daun pepaya $25 \%$ ikan rucah dengan frekuensi pemberian 1 kali). Kelangsungan hidup pada perlakuan kontrol mencapai $100 \%$ atau yang tertinggi karena ikan pellet yang diberikan kepada ikan memiliki daya tahan dalam air sehingga 100\% dapat dimakan oleh ikan, selain itu pellet komersial memiliki nutrisi yang lengkap untuk menunjang pertumbuhan dan kelangsungan hidup ikan. Kelangsungan hidup ikan ditentukan oleh beberapa faktor, diantaranya kualitas air meliputi suhu, salinitas, kadar amoniak, oksigen yang terlarut, dan tingkat keasaman $(\mathrm{pH})$ perairan, serta ratio antara jumlah pakan, frekuensi dan kepadatan (Gustaf, 1998). Untuk perlakuan yang diterapkan pada penelitian ini, perlakuan p2f3 (50\% ikan rucah $\& 50 \%$ daun papaya) memberikan pengaruh terhadap kelangsungan hidup ikan 97,22\%. Tingkat kelangsungan hidup ikan dari perlakuan yang diberikan memiliki perbedaan yang tidak terlalu signifikan. Kelangsungan hidup yang dihasilkan memberikan gambaran hasil interaksi antara daya dukungan lingkungan dan pakan. Ketersediaan pakan yang cukup dan berkualitas tinggi serta daya dukung lingkungan/ruang akan mengefisienkan penggunaan energy sehingga dapat dimanfaatkan oleh ikan beronang untuk mempertahankan tingkat kelangsungan hidupnya.

Selama pemeliharaan juga terjadi kematian pada beberapa ekor ikan pada hampir seluruh perlakuan, kecuali pada perlakuan p2f3 ulangan 2 dan 3. Kematian ikan terjadi umumnya pada minggu awal pemeliharaan. Hal ini diduga karena adanya stress akibat penanganan selama proses penyesuaian atau aklimatisasi. Alasan ini diperkuat oleh pendapat Effendi (1997) dalam Alnand (2013) menyatakan bahwa derajat kelangsungan hidup dipengaruhi oleh faktor biotik yaitu persaingan, parasite, umur, predator, kepadatan dan penanganan manusia.

Menurut hormone dan Rahmatun (2008), jika ketersediaan pakan selalu mencukupi maka tingkat keberhasilan pemeliharaan dapat mendekati 100\%, bahkan tidak ada yang mati/hilang. Makanan yang dimakan oleh ikan untuk kelangsungan hidup selebihnya dimanfaatkan untuk pertumbuhan sehingga peningkatan padat tebar belum tentu menurunkan kelangsungan hidup ikan (Rahman, 2003)

Manajemen pemberian pakan telah menjadi beragam tetapi aturan umum tentang pemberian pakan pada tingkat optimal harus sangat ekonomis sehingga dapat menghemat biaya pakan dan pembenaran ekonomi secara keseluruhan (Webster, et al, 1992). Pakan yang tidak mencukupi menyebabkan pertumbuhan yang buruk dan kematian ikan yang tinggi yang mengakibatkan kerugian dalam usaha budidaya perikanan. Diketahui bahwa praktik pemberian pakan yang tidak tepat dalam budidaya dapat menyebabkan pemberian pakan berlebih yang mengakibatkan limbah pakan di air tambak dan akibatnya biaya produksi yang lebih tinggi dan pencemaran lingkungan perairan. serta tingkat asupan pakan harian, frekuensi dan waktu pemberian pakan serta penyajian ransum yang telah ditentukan merupakan faktor kunci dari strategi pengelolaan pakan, yang mempengaruhi pertumbuhan dan konversi pakan. 
Naiboki Salampessy dan Irawati. Laju Pertumbuhan Dan Kelangsungan Hidup Ikan Baronang Siganus canalicalatus Yang DiberiJenis Pakan dan Frekuensi Yang Berbeda di Keramba Jaring Apung

\section{Efesiensi Pakan}

Nilai konversi pakan atau Feed Convertion Ratio (FCR) selama perlakuan dapat dilihat pada Gambar 7.

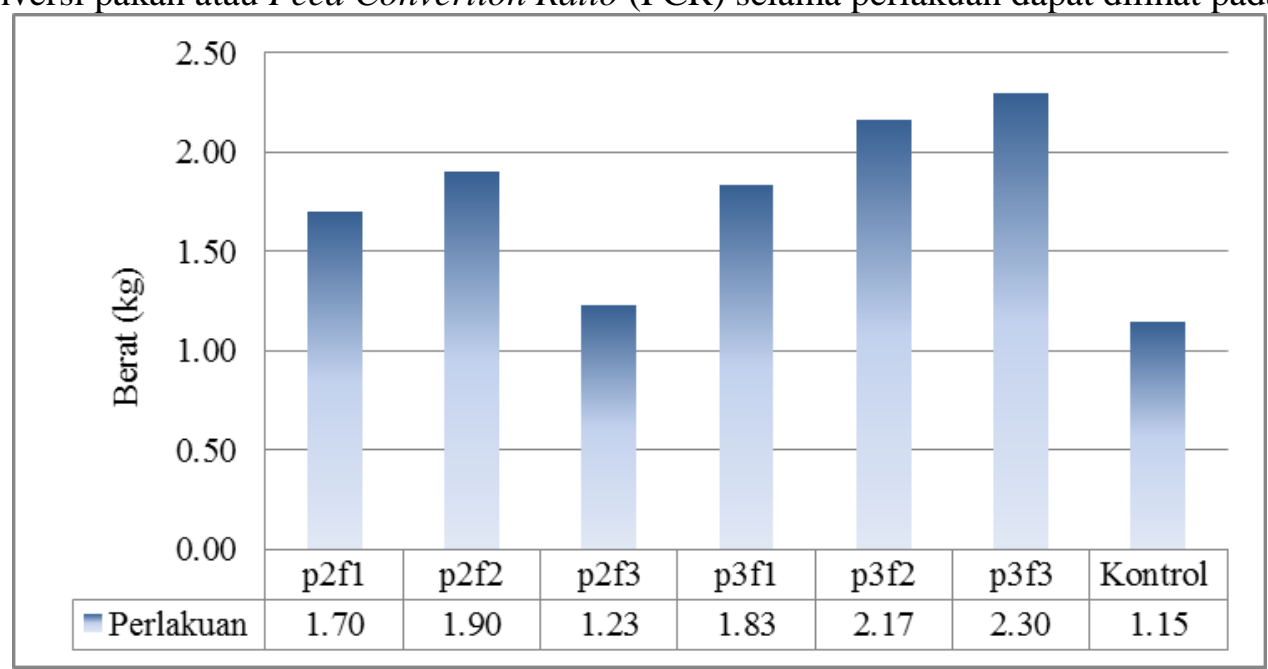

Gambar 7. Grafik efesiensi pakan (FCR) ikan barongan pemeliharaan selama 120 hari

Berdasarkan analisa statistik ragam masing-masing nilai tengah populasi setiap perlakuan (ANOVA uji $\mathrm{F}$ dua arah) pada selang kepercayaan 95\% ( $>00,05)$, diperoleh hasil bahwa perlakuan jenis dan frekuensi pakan berbeda tidak berpengaruh nyata terhadap nilai konversi pakan. Hal ini diperkuat oleh Setiawati et al. (2013), bahwa besar kecilnya nilai efisiensi pakan tersebut tidak hanya ditentukan oleh jumlah pakan yang diberikan, melainkan juga dipengaruhi oleh beberapa faktor seperti kepadatan, berat setiap individu, umur kelompok hewan, suhu air dan cara pemberian pakan (kualitas, penempatan dan frekuensi pemberian pakan).

Pada 6 perlakuan yang diaplikasikan pada penelitian ini, konversi pakan (FCR) paling rendah pada perlakuan p2f3 $(1,23)$ dan yang paling tinggi pada perlakuan p3f3 (2,30). Semakin rendah nilai FCR semakin baik, yang mengindikasikan semakin sedikit pakan yang digunakan untuk menghasilkan $1 \mathrm{~kg}$ pakan, yang berarti tingkat efisiensi pakan semakin tinggi. Secara umum, nilai FCR yang paling baik adalah pada kontrol (penggunaan pakan pellet) sedangkan untuk semua perlakuan, FCR terbaik terdapat pada perlakuan p2f3. Kombinasi 50\% sumber protein dari nabati dan $50 \%$ protein dari sumber hewani dengan frekuensi pemberian 3 kali memberikan efisiensi pakan terbaik diantara perlakuan. Sejalan dengan pendapat (Arief et al. 2016), penambahan papain pada pakan ikan akan menambahkan kandungan asam amino yang nantinya bisa dimanfaatkan oleh ikan untuk kebutuhan fisiologis serta pertumbuhan.

Menurut Halver (1972) dalam Hariyadi et al. (2005), dinyatakan bahwa semakin tinggi nilai efisiensi pakan memberikan gambaran bahwa kualitas pakan semakin baik. Ikan Beronang sebagai ikan herbivor, memerlukan bahan baku nabati dalam komposisi pakannya.

Efisiensi pemberian pakan dapat menekan biaya produksi, namun tetap memiliki nilai nutrisi yang dibutuhkan ikan merupakan alternative yang perlu diupayakan. Beberapa cara dilakukan untuk meningkatkan efisiensi pakan termasuk mengoptimalkan pencernaan dan penyerapan pakan serta peningkatan nilai efisiensi protein dengan adanya penambahan enzim pada pencernaan (Norma dkk, 2015)

Terdapat dua jenis enzim dalam pencernaan yaitu enzim endogeneous maupun enzim eksogeneous untuk membantu mempercepat proses pencernaan dan hidrolisis. Salah satu enzim eksogeneous adalah enzim papain (Winda, 2013)

Nilai konversi pakan atau feed convertion ratio (FCR) dapat menggambarkan efisiensi pakan untuk pertumbuhan. Menurut Zonneveld et al (1991) menyatakan bahwa konversi pakan menunjukkan jumlah pakan yang dibutuhkan untuk membuat daging (pertumbuhan). Nilai FCR selama pemeliharaan, perlakuan menunjukkan hasil FCR yang berbeda nyata yakni pada perlakuan jenis pakan 50\% rucah dan 50\% daun papaya dengan frekuensi 3 kali (p2f3). Pemberian pakan 50\% rucah dan 50\% daun papaya memberikan nilai konversi yang lebih rendah dari perlakuan lainnya. Ini merupakan indikator bahwa dengan pakan jenis tersebut terbukti yang terbaik dalam pemeliharaan ikan Beronang selama penelitian ini. Akan tetapi dilihat dari segi efektifitas dan efisiensi (waktu dan biaya) dalam kegiatan budidaya, nilai FCR pada perlakuan p3f1 dengan jenis pakan 25\% ikan rucah dan $75 \%$ daun papaya dengan frekuensi pemberian 1 kali sehari lebih baik diantara semua perlakuan.

Efisiensi pakan diperlukan agar dalam kegiatan budidaya mendapatkan kombinasi pakan yang mampu menghasilkan output maksimal. 
Naiboki Salampessy dan Irawati. Laju Pertumbuhan Dan Kelangsungan Hidup Ikan Baronang Siganus canalicalatus Yang DiberiJenis Pakan dan Frekuensi Yang Berbeda di Keramba Jaring Apung

\section{Kualitas Air}

Secara umum berdasarkan hasil pengukuran kualitas air tersebut diketahui bahwa kualitas air masih memiliki nilai kisaran optimal untuk kelayakan budidaya ikan Beronang di keramba jaring apung. Dapat dilihat pada Tabel 3.

Tabel 3. Data kualitas air pada pemeliharaan ikan beronang selama 120 hari

\begin{tabular}{|c|c|c|c|c|c|c|c|}
\hline \multirow{2}{*}{$\begin{array}{l}\text { Parameter } \\
\text { Kualitas Air }\end{array}$} & \multicolumn{5}{|c|}{ Perlakuan } & & \multirow[t]{2}{*}{ *Baku Mutu } \\
\hline & p2f1 & $\mathrm{p} 2 \mathrm{f} 1$ & $\mathrm{p} 2 \mathrm{f} 1$ & $\mathrm{p} 2 \mathrm{f} 1$ & $\mathrm{p} 2 \mathrm{f} 1$ & p2f1 & \\
\hline Suhu & $27,8-29$ & $27,8-29$ & $27,8-29,5$ & $28-29$ & $28-29$ & $28-29$ & $28-32^{\circ} \mathrm{C}$ \\
\hline Salinitas & $31-33 \%$ & $31-33 \%$ & $31-33 \%$ & $30-32 \%$ & $30-32 \%$ & $31-32 \%$ & $17-37 \%$ \\
\hline DO & $5.96-6.65$ & $5.96-6.65$ & $5.96-6.65$ & $5.60-6.50$ & $5.80-6.55$ & $6.05-6.55$ & $>5$ \\
\hline pH & 8,2 & 8,2 & 7,8 & 8,1 & 7,8 & 7,8 & $6,5-8,5$ \\
\hline
\end{tabular}

* Sumber : Keputusan Menteri Negara Lingkungan Hidup Tahun 2004

*) sangat bervariasi dan tidak dapat dikontrol

Serta menurut M.Ghufran H. Kordi k, 2005 menyatakan bahwa parameter kualitas air yang sangat baik untuk budidaya ikan dengan sistem keramba jaring apung yakni kisaran suhu $25-31^{\circ} \mathrm{C}$, salinitas $28-32 \mathrm{ppt}, \mathrm{pH} 7,2-8,5$ dan oksigen terlarut 3-4 ppm sedangkan menurut Lam, 1974 menyatakan bahwa kisaran suhu 23-34 ${ }^{\circ} \mathrm{C}$, salinitas $17-37$ ppt, $\mathrm{pH}>9$ ikan sangat sensitive, oksigen terlarut 2 ppm, sehingga dibandingkan dengan hasil pengukuran kualitas air selama penelitian diketahui bahwa kualitas air masih memiliki nilai kisaran optimal untuk kelayakan budidaya ikan Beronang di keramba jaring apung.

Rata-rata nilai suhu perairan pada lokasi penelitian berkisar $27-29^{\circ} \mathrm{C}$ yang masih berada pada kisaran normal sesuai standar baku mutu kualitas air laut untuk biota Menurut Keputusan Menteri Negara Lingkungan Hidup Tahun 2004 (Tabel 11). Metabolisme tubuh ikan akan berjalan optimal pada suhu yang optimal. Sesuai dengan batas toleran ikan yang berbeda-beda. Selain itu, suhu juga menjadi salah satu faktor yang dapat mempengaruhi pertumbuhan ikan karena dapat mempengaruhi nafsu makan ikan.

Kisaran nilai salinitas perairan selama penelitian berkisar 31-33\%, yang masih optimal bagi pertumbuhan kehidupan ikan beronang. Menurut Laevastu \& Hayes (1982), setiap jenis ikan memiliki kemampuan yang berbeda untuk beradaptasi dengan salinitas perairan laut, dan sebagian besar bersifat stenohaline. Menurut Lam (1974), S.canaliculatus dapat mentoleransi perubahan salinitas sampai $5 \%$ dan sangat sensitif terhadap nilai pH perairan di atas 9. Salinitas merupakan salah satu faktor lingkungan yang mempengaruhi kemampuan organisme untuk hidup, tumbuh, memanfaatkan pakan dan berperan dalam lingkungannya. Salinitas pada perairan berhubungan erat dengan sistem (mekanisme) osmoregulation pada suatu organisme. Proses osmoregulation memerlukan energi yang besar. Hal ini yang mempengaruhi jumlah pakan yang dimakan oleh ikan Beronang.

Kadar oksigen (DO) di perairan, memiliki kadar oksigen rata-rata sebesar 8,2 mg/l, hal ini sesuai dengan ketentuan SNI 8036.2:2014 dengan DO untuk pemeliharaan ikan laut ukuran 75 hari ke atas adalah lebih dari $4 \mathrm{mg} / \mathrm{l}$. Suhu adalah faktor yang dapat mempengaruhi tingkat oksigen yang terlarut pada air (DO).

Derajat keasaman $(\mathrm{pH})$ yang terlalu rendah atau terlalu tinggi dapat mempengaruhi terhadap pertumbuhan ikan dan mengakibatkan terjadinya stress pada ikan. Keputusan Menteri Negara Lingkungan Hidup Tahun 2004. Budidaya Ikan Laut, $\mathrm{pH}$ yang optimal untuk pemeliharaan ikan laut termasuk Beronang dengan usia di atas 75 hari adalah 7,5-8,5. Sementara itu, $\mathrm{pH}$ air di perairan dimana penelitian dilakukan adalah 8 dan dapat dikatakan sesuai dengan baku mutu.

\section{DAFTAR PUSTAKA}

Abdul Rauf, 2018. Analisis Kesesuaian dan Daya Dukung Lahan Budidaya Ikan Beronang Siganus canaliculatus Pada Ekosistem Lamun di Wilayah Pesisir Kabupaten Barru, Sulawesi Selatan. Volume 2 (1) Desember $2018: 15-22$

Afrianto, E dan E. Liviawaty. 2005. Pakan Ikan. Kanasius. Yogyakarta

Agid Faisal H, Rita Rostika, Mochamad Untung Kurnia Agung dan Kiki Haetamy, 2019. Pemanfaatan simlisia papaya pada ikan rucah untuk pakan kerapu cantang Ephinepelus fuscoguttatus lanceulatus di Keramba Jaring Apung di Pesisir Pangandaran. Jurnal Perikanan dan Kelautan Vol. X. No 2/Desember 2019 (56-64). Universitas Padjajaran

Ahmad Fhadil Hasan, Adi Susanto dan Andi Nikhlani, 2015. Pengaruh Air Perasan Daun Pepaya Terhadap Efisiensi Pakan dan Pertumbuhan Ikan Lele Sangkuriang Clarias sp. Fakultas Perikanan dan Ilmu Kelautan Universitas Mulawarman. Jurnal Ilmu Perikanan Tropis Vol.21. No.1, Oktober 2015.

Allen, K. O. 1974. Effects of stocking density and water exchange rate on growth and survival of channel catfish Ictalurus punctatus (Rafinesque) in circular tanks. Aquaculture 4:29-39 
Naiboki Salampessy dan Irawati. Laju Pertumbuhan Dan Kelangsungan Hidup Ikan Baronang Siganus canalicalatus Yang DiberiJenis Pakan dan Frekuensi Yang Berbeda di Keramba Jaring Apung

Amalia, R, Subadiyono dan Endang A. 2013. Pengaruh Penggunaan Papain terhadap Tingkat Pemanfaatan Protein Pakan dan Pertumbuhan Lele Dumbo (Clarias gariepenus) Jurnal of Aquaculture Management andTechnology.2(1):136-143.

Arief, M., A. Manan \& C.A. Pradana. 2016. Penambahan papain pada pakan komersial terhadap laju pertumbuhan, rasio konversi pakan dan kelulushidupan ikan sidat (Anguilla bicolor) stadia elver. Jurnal Ilmiah Perikanan dan Kelautan. 8 (2) : 67-76

Agus Rochdianto, 1995. Budidaya Ikan Di Jaring Terapung. Penerbit Penebar Swadaya Anggota IKAPI

Aziz, 1989. Dinamika Populasi Ikan. Bogor: IPB.

Basyari, A., 1988 Biologi dan Budidaya ikan Beronang Siganus spp. Wicara/Seminar Pemanfaatan Sumberdaya Pantai/Laut. Sub Balai Penelitian Budidaya Pantai Bojonegara, Serang Bojonegara, 12-13 April 1988, pp. 120

Basyori, A., E. Dana Kusumah; Philip T. T, Pramu, S, Musthahal dan M. Isra. Budidaya Ikan Beronang (Siganus spp). Direktorat Jenderal Perikanan bekerjasama dengan IDRC, 39 pp.

Britner, A., E. Omar, A.M. Nour. 1989. Budidaya Air. Jakarta: Yayasan Obor Indonesia.

Cowey, C.B. 1994. Amino acid requirements of fish: a critical appraisal of present values. Aquaculture, 124: 1-11.

Dana Kusumah, E., 1985, Beberapa Aspek Biologi Ikan Beronang (Siganus spp) Workshop Budidaya Laut 28 Oktober - 1 Nopember 1985 di Lampung. 10 pp.

Dana Kusumah, E. 1986. Beberapa Aspek Biologi Ikan Beronang (Siganus spp). Sub Balai Penelitian Budidaya Pantai Bojonegara. Lampung.

D.A.J. Selano, N.Chr. Tuhumury dan Fransisco M. Handoyo, 2016. Status Kualitas Air Perikanan Keramba Jaring Apung Dalam Pengelolaan Sumber Daya Perikanan Di Teluk Ambon Bagian Dalam. Jurnal TRITON Volume 12. Nomor 1. April 2016, hal 42-60

De Silva, S.S. (1987). Finfish Nutrition Research in Asia. Proceeding of The Second Asian Fish Nutrition Network Meeting. Heinemann, Singapore. 128 pp.

Direktorat Jenderal Perikanan Budidaya, 2002. Statistik Perikanan Budidaya Indonesia, Jakarta

Diana Rachmawati, Johannes Hutabarat, Istiyanto Samidjan, 2016. Aplikasi Enzim Papain Dalam Pakan Buatan Sebagai Pemacu Pertumbuhan Upaya Percepatan Produksi Lele Sangkuriang Di Kawasan Kampung Lele Desa Wonosari Program Studi Budidaya Perairan, FPIK, UNDIP. Prosiding Seminar Nasional Kelautan 2016

Dr. Ir. I Nyoman Suyasa, MS, Moch. Nurhudah, M.Sc, Sinung Rahardjo, M.Si, 2010. Ekologi Perairan. Penerbit STP Press

Effendie, M.I. 1979. Metode Biologi Perikanan. Bogor: Yayasan Pustaka Nusantama

Effendie, M.I. 1997. Biologi perikanan. Yayasan Pustaka Nusatama. Yogyakarta.

Effendi, H. 2003. Telaah Kualitas Air bagi Pengelolaan Sumber Daya dan Lingkungan Perairan. Cetakan Kelima. Yogjakarta : Kanisius.

Fadli, J., Sunaryo \& A, D. 2013. Pemberian Enzim Papain Pada Pakan Komersil Terhadap Pertumbuhan dan Efisiensi Pakan Ikan Kerapu Macan Epinephelus fuscogutattus. Journal Of Marine Research, 2(3), 50-57.

Fauzi, I. A., Mokoginta, I., \& Yaniharto, D. 2008. Pemeliharaan Ikan Kerapu Bebek (Cromileptes Altivelis) Yang Diberi Pakan Pelet Dan Ikan Rucah Di Keramba Jaring Apung. Jurnal Akuakultur Indonesia, 65-70

Fitrinawati, H. 2004. Kebiasaan Makan Ikan rejung (Sillago sihama) di Perairan Pantai Manyangan, Subang, Jawa Barat. Skripsi, Institut Pertanian Bogor, Bogor

Gundermann, M., D.M. Popper dan L.Lichatowich, 1983. Biology and life cycle of Siganus vermiculatus (Siganidae, Pisces). Pacific Sci. 32 (2), 165 - 180.

Gwiter D and DJ. Groves,1979.Physiological Energetics In;WS Hoar, Randall and JR Brett (Eds). Fish Physiology Vol VIII, 279-351. Academic Press. New York.

Gwiter D, and DJ Grove. 1981. Gastric Empyting in Limanda Limanda L, and Return Of Appetetic. s.1. : J. Fish Biol, 1981. hal 18 (3). 145-259

Halver, J. 1989. Fish Nutrition. Acad. Press. New York.

Hasting, W.H. .1976. Fish Nutrition and Fish Feed Manufacture. Red From FAO, FIR:AQ/79/R.23. Rome, Italy. $13 \mathrm{pp}$

Hariyadi, B. A. Haryono dan U. Susilo. 2005. Evaluasi efisiensi pakan dan efisiensi protein pakan ikan karper (Ctenopharyngodon idella) yang diberi pakan dengan kadar karbohidrat dan energy yang berbeda. Fakultas Biologi. Universitas Soedirman. Purwokerto Banyumas. Jawa Tengah

Hepher, B dan Y. Pruginin. 1981. Comemrcial Fish Farming: With Special Reference to Fish Culture In Israel. John Wiley and Sons. New York.

Hieking CF, 1971. Fish Culture. Faber and Faber. London

Hoar, W. S. 1975. General and Comparative Physoilogy. Prentice hall of India, New Delhi. P 319-758 
Naiboki Salampessy dan Irawati. Laju Pertumbuhan Dan Kelangsungan Hidup Ikan Baronang Siganus canalicalatus Yang DiberiJenis Pakan dan Frekuensi Yang Berbeda di Keramba Jaring Apung

Holik,F., A.G. Jagatraya, R.P. Poernomo dan A. Jauzi. 2005. Akuakultur Tumpuan Harapan Masa Depan Bangsa. Masyarakat Perikanan Nusantara dengan Taman Akuarium Air Tawar TMII. Jakarta.

Huet, M. 1971. Textbook of Fish Culture: Breeding and Cultivation of Fish. Two Edition. Fishing New Book Ltd. London.

Hasan, O.D.S. 2000. Pengaruh pemberian enzim papain dalam pakan buatan terhadap pemanfaatan protein dan pertumbuhan benih ikan Guram(Osphronemus Pascasarjana IPB, Bogor. $75 \mathrm{hlm}$

Huet, M.1970.Texbook of fish culture. Fishing News (Book Ltd.).London 63-76pp.

Husain Latuconsina, Ridwan Affandi, M. Mukhlis Kamal dan Nurlisa A. Butet, 2020. Distribusi Spasial Ikan Beronang Siganus canaliculatus Park. 1797 pada Habitat Padang Lamun Berbeda di Teluk Ambon Dalam. Departemen Biologi, FMIPA-UNISMA Malang. Jurnal Ilmu dan Teknologi Kelautan Tropis Vol.12 No.1 HIm. 89-106

Husnun H, dkk 2015. Analisis Proksimat pada Kangkung Air. Jurusan Teknologi Pertanian Fakultas Teknologi Industri Pertanian Universitas Sahid Jakarta

Hutabarat, J. 2005. Pakan Buatan Ramah Lingkungan. PS. Budidaya Perairan Jurusan Perikanan FPIK UNDIP. 41 hlm.

Indah, M. S. 2007. Struktur Protein. Fakultar Kedokteran, Univesitas Sumatra Utara, Medan. 89 hlm.

Irawati, 2016. Kinerja Pertumbuhan Kelangsungan Hidup Udang Vaname Litopenaeus vannamei Dengan Jenis Dan Frekuensi Pakan Berbeda Di Keramba Jaring Apung

Ir. Budi Samadi, 2010. Pembesaran ikan dalam Keramba Jaring Apung. Penerbit Titian Ilmu Bandung

Ir. Budi Samadi, 2009. Pembesaran Ikan Di Perairan Umum dalam Keramba Jaring Apung. Penerbit Titian Bandung Irianto A. 2010. Statistika Konsep, Dasar, Aplikasi, dan Pengembangannya. Kencana Prenada Media Group. Jakarta

Ishak, A. 2001. Komposisi Makanan Iktio fauna yang Dominan Tertangkap di Daerah Padang Lamun Tanjung Tiram. Skripsi. Fakultas Pertanian Jurusan Perikanan. Universitas Halu Oleo. Kendari.

Jauharul Fadli, Sunaryo, Ali Djunaedi, 2013. Pemberian Enzim Papain pada Pakan Komersil Terhadap Pertumbuhan dan Efisiensi Pakan Ikan Kerapu Macan (Epinephelus fuscoguttatus) Program Studi Ilmu Kelautan, Fakultas Perikanan dan Ilmu Kelautan, Universitas Diponegoro. Journal Of Marine Research. Volume 2, Nomor 3, Tahun 2013, Halaman 50-57

Jobling, M., Gomes, E \& Dias, J.2001. Feedtype, manufacture and ingredients. In Houlihan, D, Baujard, T, \& Jobling, M (ED) Food intake in Fish. Blackwell Science Ltd. A Blackwell Pubshing Company. Malden, USA, p. 25-48

Keputusan Menteri Lingkungan Hidup, 2004. Keputusan Menteri Lingkungan Hidup Nomor 51 tentang Baku Mutu Air Laut Untuk Biota Laut

Khouw,A.S.,2015. Metode dan Analisa Kuntitatif Dalam Bioekologi Laut.Ambon

Kono H and Y Nose, 1971. Relationship between the amount Of Food Take And Growth In Fishes. I Frequency Of Feeding For Maximum Daily Ration. Bull. Jap. Soc. Sei. Fish 37 (3). 169-179

Kune S. 2007. Pertumbuhan Rumput Laut yang Dibudidayakan Bersama Ikan Baronang. Jurnal Agrisistem. 3(1): 3442

Kurnia, B.S. Akbar, dan Salam, 2000. Penggelondongan ikan kerapu macan dengan pakan buatan yang mengandung Prosentase. Ikan Rucah Berbeda. Jurnal Kegiatan Balai Budidaya Laut Lampung

Lam, T.J, 1974. Siganid Their Biology and mariculture potensial. Departement of Zoology University of Sinapore. $325-54 \mathrm{p}$

Masyamsir, 2001. Membuat pakan ikan buatan, Proyek Pengembangan Sistem dan Stan dari Pengelolaan SMK. Direktorat Pendidikan Menengah Kejuruan Jakarta. Hal. 32.

Mayunar, 1992. Jenis-jenis ikan karang ekonomis penting sebagai komoditi ekspor dan prospek budidayanya. Oseana.XXI (3):23-31.

Merta, I.G.S. 1980. Studi Ekologi Ikan Baronang, Siganus canaliculatus (Park 1792) di Perairan Teluk Banten, Pantai Utara Jawa Barat. [Tesis] Bogor : Sekolah Pascasarjana Institut Pertanian Bogor. $130 \mathrm{hlm}$.

M. Ghufran H. Kordi K, 2005. Budidaya Ikan Beronang . Penerbit Rineka Cipta

Milind, P., \& Gurditta. (2011). Basketful Benefits of Papaya. IRJP, 2(7), 6-12.

Moeljanto. (1994). Pengawetan dan Pengolahan Hasil Perikanan. Panebar Swadaya.

Muchtadi, D.,.S.R.Palupi, dan M.Astawan, 1992. Enzim dalam industry Pangan. Pusat Antar Universitas Pangan dan Gizi.Institut Pertanian Bogor,Bogor.118 p

Muhammad Farchan, Mugi Mulyono, 2011. Dasar-Dasar Budidaya Perikanan. Penerbit STP Press

Moeljanto. (1994). Pengawetan dan Pengolahan Hasil Perikanan. Panebar Swadaya

Mudjiman. A., 1998. Makanan Ikan. Cet-XI. Penebar Swadaya Bogor 
Naiboki Salampessy dan Irawati. Laju Pertumbuhan Dan Kelangsungan Hidup Ikan Baronang Siganus canalicalatus Yang DiberiJenis Pakan dan Frekuensi Yang Berbeda di Keramba Jaring Apung

Muliati, Farid Yasidi, Hasnia Arami, 2017. Studi Kebiasaan Makanan Ikan Beronang Siganus canaliculatus di Perairan Tondonggeu Kecamatan Abeli Sulawesi Tenggara. Jurnal Manajemen Sumber Daya Perairan, 2(4): 287-294

Norma Isnawati, Romziah Sidik dan Gunanti Mahasri, 2015. Potensi Serbuk Daun Pepaya untuk meningkatkan efisiensi pemanfaatan pakan, rasio effisiensi protein dan laju pertumbuhan relative pada Budidaya Ikan Nila

Niklosky, G. V. (1963). The Ecology of Fishes. Academic Press London. England

NRC, 1977. Nutrient Requirement Of Warm Water Fishes. National Academic Press. Washington Dc.

Rafi Setiawan, Heri Triyono, Meuthia A. Jabbar, 2019. Aspek Biologi Siganidae di Perairan Maluku. Jurnal Penyuluhan Perikanan dan Kelautan Volume 13 (3) Desember 2019 Halaman 287-300

Rachmansyah, S. Tonnek dan Usman. Produksi Ikan Bandeng Super Dalam Karamba Jaring Apung di Laut, 1997. Seminar Hasil-hasil Penelitian Berbasis Perikanan, Peternakan dan Sistem Usaha Tani di Kawasan Timur Indonesia, Kupang, 28-31 Juli 1997

Rasidi, M. (1998). Nutrisi Ternak Unggas Makanan Broiler. Jakarta : PT Gramedia Pustaka Utama.

Renhoran, M., A. Saraswati, Y. Aktinidia, F. Syukron dan R. K. Rukmana. 2011

Rika. 2008. Pengaruh Salinitas Terhadap Pertumbuhan dan Kelulusan Ikan Hasil Strain GIFT dengan Strai

Singapura. Skripsi, Universitas Diponegoro. Semarang.

Rittner D, Bailey RA. 2005. Encyclopedia of Chemistry. Facts on File: AS.

Robinson, C. et.al. (1995). Authoritative, Authoritarian and Permissive Parenting Practices: Development of a New Measure. Psychological Reports,77,819-830

Rohim Dahuri, 2004, Paradigma Baru Pembangunan Indonesia Berbasis Kelautan. IPB Press

Romimohtarto, K dan Juwana, S. 2007. Biologi Laut. Penerbit Djambatan. Jakarta.

Rounsefell, G.A. dan W.H. Everhart. 1953. Fishery Science its Methods and Aplication. John Wiley and Sons: New York. 456 hal.

Sari, W.A.P, 2013. Pemberian Enzim Papain untuk meningkatkan Pemanfaatan Protein Pakan dan Pertumbuhan Benih Ikan Nila Larasati. Oreochromis Var). Jurnal of Aquaculture Management and Technology, 2 (1) : 112

Setiawati, J. E. T., Y.T. Adiputra., dan S. Hudaidah. 2013. Pengaruh Penambahan Probiotik Pada Pakan Dengan Dosis Berbeda Terhadap Pertumbuhan, Kelulushidupan, Efisiensi Pakan Dan Retensi Protein Ikan Patin (Pangasius hypophthalmus). e-Jurnal Rekayasa dan Teknologi Budidaya Perairan. 1(2). 151-162.

Stickney, R.R. 1997. Tilapia update 1996. World Aquaculture, 28: 20-25.

Subandiyono dan S. Hastuti.2014. Beronang serta Prospek Budidaya Laut di Indonesia. UPT Universitas Dipenogoro Press. Semarang. $78 \mathrm{Hlm}$

Sugeng Hadinoto, Joice P. M. Kolanus, 2017. Evaluasi Nilai Gizi dan Mutu Ikan Layang (Decapterus sp) Presto dengan penambahan Asap cair dan Ragi. Balai Riset dan Standarisasi Industri Ambon. Majalah BIAM.

Sunaryanto, Sulistyo, Chaidir, I, dan Sudijiharno, 2001. Pengembangan Teknologi Budidaya Kerapu, Permasalahan dan Kebijakan. Prosiding Nasional Agribisnis Pengembangan Kerapu. BPPT Jakarta 28-29 Agustus 2001

Suprayudi, M.A., W. Dimahesa, D. Jusadi, M. Setiawati, J. Ekasari. 2011. Suplementasi Crude Enzim Cairan Rumen Domba pada Pakan Berbasis Sumber Protein Nabati dalam Memacu Pertumbuhan Ikan Nila (Oreochromis Niloticus). J. Iktiologi Indonesia, 11(2): 177-183.

Tietze. 2002. Terapi Pepaya. Jakarta:Prestasi Pustaka Publisher

Warisno, 2003. Budidaya Pepaya. Jogyakarta: Kanisius.

Watanabe, T (1988). Fish Nutrition and Marine Culture. JICA Text Book the General Aquaculture Broscienees. Tokyo University of Fisheries. $233 \mathrm{pp}$

Widodo, S. S. 1986. Budidaya Ikan Beronang . Balai Pengembangan Teknik Budidaya Laut. Lampung.

Widyaningrum, 2002. Analisis Proksimat pada Daun Pepaya di Laboratorium Nutrisi dan Makanan Ternak Fakultas Peternakan Institut Pertanian Bogor

Winda et al, 2013. The use of Papain Enzyme to Increase The Digestibility fo Dietary Protein and the Growth of Juveniles of Tilapian Larasati (Oreocromis niloticus, Var)

Wisnu Arya Gemilang, Guntur Adhi Rahmawan, Ulung Jantama Wisha, 2017. Kualitas Perairan Teluk Dalam Berdasarkan Parameter Fisika dan Kimia Pada Musim Peralihan I. EnviroScienteae Vol.13 No.1, April 2017, halaman 79-90

Woodland, D. J. (1990). Revision of the fish family Siganidae with descriptions of two new species and comments on distribution and biology. Indo-Pac. Fish. (19):136 p

Zonneveld, Huisman dan Boon . 1991. Prinsip-prinsip Budidaya Ikan. PT. Gramedia Pustaka Utama. Jakarta.

Umar Rifai, NirwanHendarto dan Abd Gani, 2014. Pembesaran Ikan Beronang (Siganus lineatus) pada Keramba Jaring Apung (KJA) Di Teluk Ambon Bagian Dalam. Balai Budidaya Laut Ambon. 
Naiboki Salampessy dan Irawati. Laju Pertumbuhan Dan Kelangsungan Hidup Ikan Baronang Siganus canalicalatus Yang DiberiJenis Pakan dan Frekuensi Yang Berbeda di Keramba Jaring Apung

Yuli Andriani, 2015 Pepaya Sumber Enzim Pakan Ikan. Staf Pengajar Prodi Perikanan, Fakultas Perikanan dan Ilmu Kelautan Manajer Kemahasiswaan dan Hubungan Alumni Sekolah Pascasarjana Universitas Padjadjaran 